\section{Ankara Üniversitesi Eğitim Bilimleri Fakültesi Özel Eğitim Dergisi}

2022, 23(3), 721-750
DERLEME

Gönderim Tarihi: 23.12 .20

Kabul Tarihi: 23.11.21

Erken Görünüm: 18.01.22

\title{
Zihin Yetersizliği Olan Öğrencilere Fen Öğretimine İlişkin Türkiye'de Yapılan Çalışmaların İncelenmesi
}

\author{
Çiğdem Türker-Yıldırım (iD) 1
}

$\ddot{O} z$

Giriş: Zihin yetersizliği olan öğrencilerin öğrenme hızları, tipik gelişim gösteren akranlarına göre daha yavaş gerçekleşmektedir. Bu nedenle öğrenme-öğretme sürecinin etkili bir şekilde gerçekleştirilmesi için öğrencilerin bireysel farklılıkları, gelişimsel özellikleri ve eğitim ihtiyaçları doğrultusunda farklı müdahaleler kullanılmalıdır. $\mathrm{Bu}$ araştırmanın amacı da zihin yetersizliği olan öğrencilere fen kavram, bilgi ve becerilerinin öğretilmesi için kullanılan müdahalelerin yer aldığı, Türkiye'de gerçekleştirilmiş olan çalışmaların incelenmesidir.

Yöntem: Doküman analizi kullanılarak gerçekleştirilen bu araştırmada Google Akademik, Yükseköğretim Kurulu Ulusal Tez Merkezi ve Türkiye Bilimsel ve Teknolojik Araştırma Kurumu Ulusal Akademik Ağ ve Bilgi Merkezi veri tabanlarında tarama yapılmış ve ölçütleri karşılayan 17 çalışma incelenmiştir.

Bulgular: Araştırma sonucunda çalışmalarda ortaokul düzeyindeki katılımcılara ve "canlılar ve yaşam" konu alanına daha çok yer verildiği ortaya çıkarılmıştır. İncelenen çalışmaların çoğunda, doğrudan öğretim yöntemi ve teknoloji destekli öğretim müdahalelerinin yer aldığı bulgusu elde edilmiştir. Ayrıca çalışmaların büyük çoğunluğunda öğrencilerin fen kavram, bilgi ve becerileri kazandığı, fen bilimleri dersine yönelik yeterlik ve başarısının arttığı, gerçekleştirilen çalışmaların ilgi ve tutumlar üzerinde olumlu yönde değişim sağladığ bulunmuştur.

Tartışma: Araştırmaya dahil edilen çalışmalardan elde edilen bulgular, fen kavram, bilgi ve becerilerinin zihin yetersizliği olan öğrencilere kazandırıldığını göstermektedir. Bu doğrultuda öğrenme hızları tipik gelişim gösteren akranlarına göre daha yavaş olan zihin yetersizliği olan öğrencilerin, bireysel farklılıkları, gelişimsel özellikleri ve eğitim ihtiyaçları doğrultusunda gerçekleştirilen müdahalelerle, etkili bir öğrenme-öğretme süreci gerçekleştirdikleri görülmektedir. Ayrıca zihin yetersizliği olan öğrencilere fen öğretimi amacıyla farklı müdahalelerin uygulandığı, bu müdahalelerin etkililiğinin incelendiği çalışmaların gerçekleştirildiği, dolayısıyla bu çalışmaların zihin yetersizliği olan öğrencilere fen öğretimine yönelik, etkili müdahalelerin ortaya çıkarılması açısından önemli olduğu düşünülmektedir.

Anahtar sözcükler: Özel gereksinimli öğrenci, zihin yetersizliği olan öğrenci, zihin yetersizliği, fen, fen öğretimi, doküman analizi.

Atıf için: Türker-Yıldırım, Ç. (2022). Zihin yetersizliği olan öğrencilere fen öğretimine ilişkin Türkiye'de yapılan çalışmaların incelenmesi. Ankara Üniversitesi Eğitim Bilimleri Fakültesi Özel Ĕgitim Dergisi, 23(3), 721750. https://doi.org/10.21565/ozelegitimdergisi.843449

\footnotetext{
${ }^{1}$ Arş. Gör., Bolu Abant İzzet Baysal Üniversitesi, E-posta: cigdem.turkeryildirim@ibu.edu.tr, https://orcid.org/0000-00021953-0138
} 


\section{Giriş}

Özel gereksinimli öğrenciler arasında yaygın olarak görülen, zihin yetersizliği gösteren öğrenciler (Villanueva vd., 2012), bireysel farklılıkları, gelişimsel özellikleri ve eğitim ihtiyaçları açısından tipik gelişim gösteren akranlarından anlamlı derecede farklılık göstermektedir (Millı̂ Eğitim Bakanlığı [MEB], 2008; Özkan vd., 2013). Bu farklılıktan dolayı zihin yetersizliği olan öğrencilerin öğrenmeleri tipik gelişim gösteren akranlarına göre daha yavaş gerçekleşmektedir (MEB, 2008; Villanueva vd., 2012). Öğrenme hızları akranlarına göre daha yavaş gerçekleşen ancak akranları gibi kavram, bilgi ve becerileri öğrenebilen ve öğrenmeyi sürdürebilen zihin yetersizliği olan öğrencilere (Mete \& Yıldırım, 2020) sağlanan eğitimin amacı da öğrencilerin bağımsız yaşama olasılığını en üst düzeye çıkarmak ve eğitim ihtiyaçlarını karşılamaktır. Böylece zihin yetersizliği olan öğrencilerin akademik ve sosyal hayatta karşılaştı̆ı kavram, bilgi ve becerilerin öğrencilere öğretilmesi sağlanacaktır (Alptekin, 2010; Eripek, 2011).

Özel gereksinimli öğrencilere sunulan eğitim hizmetleri ve öğrencilerin eğitim hakkını koruma altına alan uluslararası düzeyde kabul gören Birleşmiş Milletler Engellilerin Haklarına Dair Sözleşme, özel gereksinimli öğrencilerin eğitiminde önemli bir yer tutan eğitimde firsat eşitliğinin sağlanmasını desteklemektedir. Ayrıca bu sözleşmede, özel gereksinimli öğrencilerin eğitiminde, etkililiği kanıtlanmış uygulamaların bireysel olarak planlanmasına dikkat edilmesi gerektiği, böylece öğrencilerin akademik ve sosyal gelişimlerinin destekleneceği belirtilmiştir (Milletlerarası Sözleşme, 2009). Özel gereksinimli öğrencilerin eğitiminde firsat eşitliğini destekleyen Fen Bilimleri Dersi Öğretim Programı da bireysel farklılıkları, gelişimsel özellikleri ve eğitim ihtiyaçları ne olursa olsun bütün öğrencilerin fen okuryazarı birey olarak yetiştirilmesini amaçlamaktadır (MEB, 2018). Fen okuryazarı olan bireyler, fen bilimlerine ilişkin temel bilgilere ve içinde bulunulan çevreyi anlamak için gerekli olan becerilere sahip olan ayrıca günlük yaşamda karşılaşılan sorunlara ilişkin çözüm üretebilen bireyler olarak açıklanmaktadır. Tüm öğrencilerin fen okuryazarı birey olarak yetiştirilmesini amaçlayan Fen Bilimleri Dersi Öğretim Programına göre, tipik gelişim gösteren öğrencilerin yanı sıra özel gereksinimli öğrencilerin de fen okuryazarı birey olarak yetiştirilmesinin gerekli olduğu görülmektedir (MEB, 2018). Ayrıca Amerika Ulusal Araştırma Merkezinin (National Research Council, [NRC]) yayımlamış olduğu Ulusal Fen Standartlarında da (National Science Education Standards, [NSES]) fen eğitiminin yaş, cinsiyet, toplumsal yapı ve yetersizlik türü gözetmeksizin, tüm bireyler için gerekli olduğu belirtilmektedir (Knight vd., 2012).

Özel gereksinimli öğrencilere sunulan, fen bilimleri dersindeki fen kavram, bilgi becerilerin öğrencilere öğretilmesi ve öğrencilerin fen okuryazarı birey olarak yetiştirilmesinde, öğretim sürecinin etkili bir şekilde gerçekleştirilmesi, içeriğin düzenlenmesi, materyaller ile ortamda çeşitli uyarlamaların yapılması oldukça önemlidir (Scruggs vd., 1998). Bu sayede gerçekleştirilen etkili uygulamalar ve öğrencilere sağlanan etkili öğretim ile günlük hayatta karşılaşılan kavram, bilgi ve becerilerin öğrencilere öğretilmesi sağlanacaktır (Salend, 1998). Fen bilimleri dersinin, önceki yıllarda zihin yetersizliği gösteren öğrencilerin önündeki engel olarak görülmesine karşın günümüzde zihin yetersizliği gösteren öğrencilerin fen kavram, bilgi ve becerileri öğrenebileceği uluslararası düzeyde de kabul edilmektedir (Knight vd., 2013). Zihin yetersizliği olan öğrencilerin fen kavram, bilgi ve becerileri öğrenebilmesi ve öğrenciler üzerindeki bu engellerin ortadan kaldırılması ise geliştirilen müdahaleler ile sağlanan etkili fen öğretimi ile mümkün olmaktadır (Knight vd., 2013; Mastropieri vd., 2001; Mastropieri vd., 1999).

Alanyazın incelendiğinde, fen kavram, bilgi ve becerilerinin zihin yetersizliği olan öğrencilere öğretilmesinde, yurtdışında gerçekleştirilmiş olan çeşitli araştırmaların (Courtade vd., 2010; Hudson vd., 2014; Jimenez vd., 2012) yer aldığ görülmüştür. Örneğin Courtade ve diğerleri (2010) tarafindan gerçekleştirilen bir araştırmada, beceri analizi ve ipucunun giderek azaltılması yöntemlerini içeren bir paket programının, zihin yetersizliği olan öğrencilerin araştırma yapma becerisi üzerindeki etkililiği incelenmiştir. Tek denekli araştırma yöntemlerinden katılımcılar arası çoklu yoklama modelinin kullanıldığı bu araştırmanın sonucunda, bütün öğretmenlerin uygulamayı başarıyla gerçekleştirdiği ve gerçekleştirilen uygulamanın öğrencilerin araştırma yapma becerisi üzerinde etkili olduğu ortaya çıkarılmıştır. Hudson ve diğerleri (2014) tarafından gerçekleştirilen bir başka araştırmada ise fen bilimleri dersine uyarlanmış, ipucunun giderek azaltılması yöntemi ile sunulan sesli okuma ve kendini izleme müdahalesinin, öğrencilerin sorulan sorulara bağımsız bir şekilde doğru yanıt verme düzeyi üzerindeki etkililiği incelenmiştir. Tek denekli araştırma yöntemlerinden katılımcılar arası çoklu yoklama modelinin kullanıldığı bu araştırmanın sonucunda, bütün öğrencilerin sorulan sorulara bağımsız bir şekilde doğru yanıt verdiği ortaya çıkarılmıştır.

Fen kavram, bilgi ve becerilerin zihin yetersizliği olan öğrencilere öğretilmesinde, Türkiye'de gerçekleştirilmiş olan araştırmalara bakılacak olursa, alanyazında yine çeşitli araştırmaların (Çevik, 2016; Çıkılı- 

INCELENMESI

Soylu vd., 2019; Demir, 2008; Kaya, 2016; Sola Özgüç \& Cavkaytar, 2016; Türker \& Çifci-Tekinarslan, 2020; Yıkmış \& Varol-Özçakır, 2019) yer aldığı görülmüştür. Örneğin Türker ve Çifci-Tekinarslan (2020) tarafından gerçekleştirilen bir araştırmada, "Besinlerin Sindirimi" konusunun öğretiminde kullanılan, doğrudan öğretim yöntemiyle birlikte tanılayıcı dallanmış ağaç tekniğinin yer aldığı öğretim planı ile "Vücudumuzda Boşaltım" konusunun öğretiminde kullanılan, sadece doğrudan öğretim yönteminin yer aldığı öğretim planının etkililik ve verimliliğ̣i karşılaştırılmıştır. Tek denekli araştırma yöntemlerinden uyarlamalı dönüşümlü uygulamalar modelinin kullanıldığı bu araştırmanın sonucunda, her iki öğretim planı arasında etkililik açısından bir farklılık görülmemişken, doğrudan öğretim yöntemiyle birlikte tanılayıcı dallanmış ağaç tekniğinin yer aldığı öğretim planının, sadece doğrudan öğretim yönteminin yer aldığı öğretim planına göre daha verimli olduğu ortaya çıkarılmıştır. Yıkmış ve Varol-Özçakır (2019) tarafından gerçekleştirilen bir başka araştırmada ise hayvanların yararları, beslenme şekli ve barınakları konulu fen içeriğinin kazandırılmasında doğrudan öğretim yöntemiyle sunulan kavram haritası tekniğinin etkililik, kalıcılık ve genellenebilirliği incelenmiş̧tir. Tek denekli araştırma yöntemlerinden yoklama evreli davranışlar arası çoklu yoklama modelinin kullanıldığı bu araştırmanın sonucunda doğrudan öğretim yöntemiyle sunulan kavram haritası tekniğinin hayvanların yararları, beslenme şekli ve barınakları fen içeriğinin kazandırılmasında etkili, kalıcı ve farklı kişilere genellenebilir olduğu ortaya çıkarılmıştır.

Ayrıca alanyazında zihin yetersizliği olan öğrencilere fen kavram, bilgi ve becerilerinin öğretilmesinde kullanılan müdahalelerin incelendiği çalışmaların bir derlemesinin ortaya konması amacıyla yurtdışında gerçekleştirilmiş olan çalışmalara bakıldığında, sınırlı sayıda çalışmaya (Knight vd., 2020; Wright vd., 2020) rastlanmıştır. Knight ve diğerleri (2020) tarafından gerçekleştirilen çalışmada, zihin yetersizliği olan bireylere fen içerik ve uygulamalarının öğretimine ilişkin 2009-2018 tarihleri arasında gerçekleştirilmiş olan araştırmaların incelenmesi amaçlanmıştır. Literatür taraması olarak gerçekleştirilmiş olan çalışmaya 15 araştırma dahil edilmiş olup çalışmada fen içerik ve uygulamalarının öğretilmesi için etkili uygulamalar belirlenmiştir. Wright ve diğerleri (2020) tarafindan gerçekleştirilen bir diğer çalışmada ise otizm ve zihin yetersizliği olan öğrencilere, video modelle öğretim yöntemi kullanılarak uygulanan Fen Teknoloji Mühendislik Matematik (Science Technology Enginering Mathematics, [STEM]) eğitimine yönelik 2012-2018 tarihleri arasında gerçekleştirilmiș çalıșmaların incelenmesi amaçlanmıştır. Literatür taraması olarak gerçekleştirilmiş olan çalışmaya 10 araştırma dahil edilmiş olup çalışmada kullanılan video modelle öğretim yönteminin STEM eğitimi üzerinde etkili sonuçlar ortaya çıkardığı belirlenmiştir. Ancak alanyazın incelendiğginde, Türkiye'de gerçekleştirilen ve zihin yetersizliği olan ögrencilere fen kavram, bilgi ve becerilerinin öğretilmesinde kullanılan müdahalelerin incelendiği çalışmaların derlenmesi amacıyla gerçekleştirilmiş olan bir çalışmaya rastlamamışıtır.

Fen bilimleri dersine yönelik tüm öğrencilerin temel bilgi ve becerileri öğrenip, günlük yaşamda uygulayabilmesi, Fen Bilimleri Dersi Öğretim Programının genel amacını oluşturmaktadır. Bu amacın gerçekleştirilmesi ise salt bilginin aktarılması yerine bireysel farklılıkların dikkate alınarak, tüm öğrencilere bilgi ve beceri kazandırmayı hedefleyen etkili bir öğrenme-öğretme süreci ile mümkün olmaktadır (MEB, 2018). Buna istinaden bu araştırmanın, fen bilimleri dersindeki öğrenme-öğretme sürecinin, öğretmen ve öğrencilerle birlikte etkili bir şekilde gerçekleşmesi, bu öğrenciler arasındaki zihin yetersizliği olan öğrencilerin temel bilgi ve becerileri öğrenip, günlük yaşamda sergileyebilmesi için etkili uygulamaları ortaya çıkardığı düşünülmektedir. Öğrenme-öğretme sürecinin etkili bir şekilde gerçekleştirilmesi ve buna yönelik tüm öğrencilerin gelişim ve öğrenme özelliklerine uygun, farklı uygulamaların kullanılması aynı zamanda öğretmenlik mesleğinin genel yeterlikleri arasında da yer almaktadır (MEB, 2017). Buna yönelik olarak da bu araştırmanın zihin yetersizliği olan öğrencilerle çalışan öğretmenlere farklı ve etkili uygulamalar konusunda yol göstereceği düşünülmektedir. Sonuç olarak bu araştırma, zihin yetersizliği olan öğrencilere fen öğretimine ilişkin, Türkiye'de gerçekleștirilmiş olan çalışmaları incelediği ve zihin yetersizliği olan öğrencilere fen öğretiminde etkili müdahaleleri ortaya koyduğu için önemli görülmektedir. Ayrıca bu araştırmanın, zihin yetersizliği olan öğrencilere fen öğretimi konusunda çalışacak araştırmacılara faydalı olacağı ve ilgili alanyazına katkı sağlayacağı düşünülmektedir.

$\mathrm{Bu}$ bağlamda, bu araştırmada zihin yetersizliği olan öğrencilere fen kavram, bilgi ve becerilerinin ögretilmesi için kullanılan müdahalelerin yer aldığı, Türkiye'de gerçekleştirilmiş olan çalışmaların incelenmesi amaçlanmıştır. $\mathrm{Bu}$ amaç doğrultusunda çalışmalar, çalışmanın amacı, çalışmanın yöntemi, katılımcılar ve özellikleri (sınıf düzeyi, sayı, cinsiyet, tanı), fen konu alanı, müdahale, müdahale süresi, veri toplama aracı, geçerlik ve güvenirlik verileri ile bulgular kategorilerine göre analiz edilmiştir. 


\section{Yöntem}

Bu araștırmanın amacı zihin yetersizliği olan öğrencilere fen kavram, bilgi ve becerilerin öğretilmesi için kullanılan müdahalelerin yer aldığı, Türkiye'de gerçekleştirilmiş olan çalışmaların incelenmesidir. Bu amaç doğrultusunda bu kısımda araştırmanın yöntemine ilişkin bilgi verilecektir.

\section{Araştırma Yöntemi}

Araştırma kapsamında zihin yetersizliği olan öğrencilere fen kavram, bilgi ve becerilerin öğretilmesi için kullanılan müdahalelerin yer aldığı, Türkiye'de gerçekleştirilmiş olan çalışmaların nitel doküman analizi yapılmıştır. Doküman analizi, tek başına bir araştırma yöntemi olarak ya da diğer nitel araştırma yöntemlerine ek olarak kullanılabilecek, araştırmanın konusuna yönelik bilgi ya da bilgiler içeren yazılı materyallerin analizini kapsamaktadır (Yıldırım \& Şimşek, 2018).

\section{Veri Toplama Süreci}

Araştırmanın amacı doğrultusunda çalışmalar için Google Akademik (Google Scholar), Yükseköğretim Kurulu (YÖK) Ulusal Tez Merkezi ve Türkiye Bilimsel ve Teknolojik Araştırma Kurumu Ulusal Akademik Ağ ve Bilgi Merkezi (TÜBİTAK ULAKBİM) veri tabanlarında tarama yapılmış ayrıca ulaşılan çalışmaların kaynakçalarından elle tarama yapılmıştır. Tarama yapılırken özel eğitim, özel gereksinimli birey, zihin yetersizliği ve fen anahtar sözcüklerinden yararlanılmıştır. Tarama sürecinde ilk olarak belirlenen anahtar sözcükler ile herhangi bir yıl kısıtlaması yapılmaksızın veri tabanları taranmış ve 56 çalışma elde edilmiştir. İkinci aşamada zihin yetersizliği olan öğrencilerle gerçekleştirilmeyen ve fen kavram, bilgi ve becerilerin bir müdahale ile öğretimini içermeyen 39 çalışma araştırmanın dışında tutulmuştur. Araştırmanın dışında tutulan çalışmaların özelliklerine bakılacak olursa, çalışmalarda zihin yetersizliği gösteren öğrencilerin yerine görme yetersizliği (Kahveci, 2004; Karakoç, 2016; Kızılaslan \& Sözbilir, 2017a, 2017b; Kızılaslan vd., 2020; Sözbilir vd., 2019; Teke, 2017; Tuncer \& Kahveci, 2009; Yazıc1, 2017; Zorluoğlu \& Sözbilir, 2017), özel öğrenme güçlüğü (Arac1, 2019; Biçer, 2019; İlik, 2009; Karaer \& Melekoğlu, 2020; Köse-Biber, 2009; Nas vd., 2019; Yılmaz, 2018), işitme yetersizliği (Akay, 2011; Aktürel, 2004; Şağban, 2000) ve otizm spektrum bozukluğu (Aslan vd., 2018; Elmac1, 2018; Sazak-Pınar \& Merdan, 2016) olan öğrencilerin yer aldığı görülmüştür. Ayrıca yapılan çalışmalar arasında çoklu yetersizlik (Bilgiç \& Şafak, 2020; Y1lmaz, 2017) ve bedensel yetersizlik (Peker \& Taş, 2017) gösteren öğrencilerin yer aldığı da ortaya çıkarılmıştır. Ek olarak üstün yetenekli (Akdağ vd., 2017; Ayverdi, 2018; Balım, 2016; Barış \& Ecevit, 2019; Dönmez \& İdin, 2017; Kanl1, 2008; Özdemir, 2017; Susam, 2012; Umar, 2014) ve dezavantajlı (Yeşildağ-Hasançebi \& Günel, 2013) öğrencilerin yer aldığı çalışmalara da rastlanmıştır. Bunların yanı sıra çalışmalar arasında zihin yetersizliği olan öğrencilere yönelik olup, fen kavram, bilgi ve becerilerinin bir müdahale ile öğretimini içermeyen çalışmalara da rastlanmıştır. Örneğin Kaplan ve Çifci-Tekinarslan (2013) tarafından gerçekleştirilen bir çalışmada zihin yetersizliği olan ve olmayan öğrencilerin fen kavramlarına yönelik bilgi düzeyi karşılaştırılmıştır. Mete ve diğerleri (2017) tarafından gerçekleştirilen bir çalışmada da zihin yetersizliği olan öğrencilere fen öğretimine yönelik gerekli olan unsurların yanı sıra eksiklik ve sorunların ortaya konulması amaçlanmıştır. Mete ve Yıldırım (2018) tarafından gerçekleştirilen bir başka çalışmada ise fen kavramlarının öğretilmesinde kullanılacak olan materyaller belirlenmiş ve materyal seçiminde dikkat edilecek unsurlar ortaya çıkarılmıştır. Üçüncü aşamada ise araştırmaya dahil edilen çalışmaların kaynakçalarından da elle tarama yapılmış ve elde edilen yeni çalışmalar araştırmaya dahil edilmiştir. Sonuç olarak toplamda 17 çalışmaya ulaşılmış ve ulaşılan bu çalışmalar ölçütler bağlamında incelenmiştir.

\section{Verilerin Analizi}

Araştırmaya dahil edilen çalışmalar betimsel analiz kullanılarak incelenmiştir. Betimsel analiz sürecinde elde edilen çalışmalar numaralandırılmış ve (a) çalışmaların fen kavram, bilgi ve becerilerinin öğretimi ile ilgili olması, (b) çalışma grubunu oluşturan öğrencilerin zihin yetersizliğinin olması, (c) müdahalenin öğrencilere yönelik olması ölçütlerine göre gruplandırılmıştır. Ayrıca belirlenen ölçütlere göre elde edilen çalışmaların 2008 ve 2020 yılları arasında olması nedeniyle, bu araştırmada 2008-2020 yılları arasında gerçekleştirilen çalışmalar yer almıştır. Çalışmaya dahil edilen araştırmaların güvenirliğinin belirlemesi amacıyla, seçilen anahtar sözcükler bağımsız bir uzman tarafından aynı veri tabanlarında taranmış, ulaşılan çalışmaların kaynakçalarından elle tarama yapılmış ve araştırmaya dâhil edilen çalışmaların uygunluğu kontrol edilmiştir. Güvenirlik verileri (Görüş Birliği / Görüş Birliği + Görüş Ayrılığı x 100) formülü ile hesaplanmış ve sonuç olarak çalışmaya dahil edilen araştırmaların güvenirliği \%100 olarak hesaplanmıştır. Daha sonra çalışmalar; çalışmanın amacı, çalışmanın yöntemi, katılımcılar ve özellikleri (sınıf düzeyi, sayı, cinsiyet, tanı), fen konu alanı, müdahale, müdahale süresi, veri toplama aracı, geçerlik ve güvenirlik verileri ile bulgular kategorilerine göre analiz edilmiştir. 
Gerçekleştirilmiş olan analizin güvenirliğine yönelik ise araştırmaya dahil edilen çalışmaların \%30’u $(n=5)$ yansız atama yoluyla belirlenmiş ve bağımsız bir uzman tarafından belirlenen kategorilere yönelik çalışmalardan elde edilen verilerin uygunluğu kontrol edilmiştir. Güvenirlik verileri yine (Görüş Birliği / Görüş Birliği + Görüş Ayrılığı x 100) formülü ile hesaplanmış ve sonuç olarak gerçekleştirilen analizin güvenirliği \%100 olarak hesaplanmıştır.

\section{Bulgular}

$\mathrm{Bu}$ araştırmada 2008-2020 yılları arasında zihin yetersizliği olan öğrencilere fen kavram, bilgi ve becerilerin öğretilmesi için kullanılan müdahalelerin yer aldığı, Türkiye'de gerçekleştirilmiş olan 17 çalışma incelenmiştir. İncelenen çalışmaların yıllara göre dağılımı Şekil 1'de yer almaktadır.

\section{Şekil 1}

Çalışmaların Yıllara Göre Dağıllımı

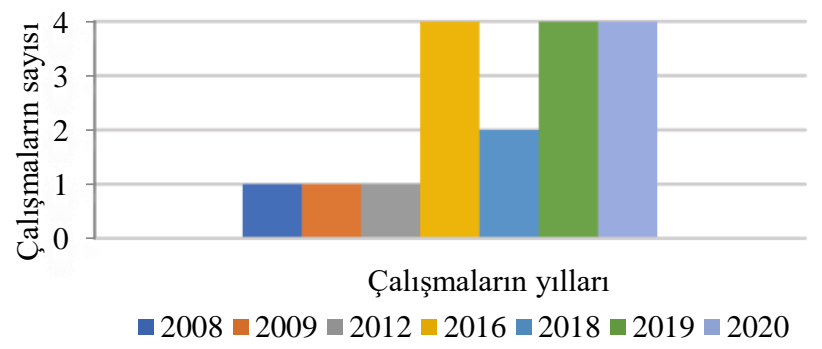

Çalışmaların yıllara göre dağılımı incelendiğinde 2008, 2009, 2012, 2016, 2018, 2019 ve 2020 yıllarında yayımlanan 17 çalışma olduğu görülmektedir. Ayrıca bu 17 çalışma; çalışmanın amacı, çalışmanın yöntemi, katılımcılar ve özellikleri (sınıf düzeyi, sayı, cinsiyet, tanı), fen konu alanı, müdahale, veri toplama aracı ve bulgular olmak üzere sekiz kategoriye ayrılmış ve bu kategorilere yönelik çalışmalardan elde edilen bilgiler Tablo 1'de özet halinde sunulmuş̧ur.

\section{Çalışmaların Amaçlarına Göre Dağılımları}

Zihin yetersizliği olan öğrencilere fen kavram, bilgi, becerilerin öğretiminde yapılan çalışmaların amaçlarına göre dağılımları Şekil 2'de yer almaktadır. Çalışmaların amaçları incelendiğinde, bu çalışmaların 10'unun müdahalenin etkililiğinin incelenmesi (Çapraz, 2016; Demir, 2008; Demircioğlu \& Kavgac1, 2020; Karasu, 2019; Kaya, 2016; Mete \& Yıldııı, 2020; Öner, 2018; Tezcan, 2012; Yıkmış \& Varol-Özçakır, 2019; Yozgat vd., 2018), dördünün yeterlik, başarı, ilgi ve tutum üzerindeki değişimin incelenmesi (Çevik, 2016; Kocadağ, 2009; Sola-Özgüç \& Cavkaytar, 2016; Tosun, 2019) ve üçünün müdahalenin etkililiğinin karşılaştırılması (Çıkılı-Soylu vd., 2019; Karabulut, 2020; Türker \& Çifci-Tekinarslan, 2020) amacıyla yapıldığı görülmüştür.

\section{Şekil 2}

Zihin Yetersizliği Olan Öğrencilere Fen Kavram, Bilgi, Becerilerin Öğretiminde Yapılan Çalı̧̧maların Amaçlarına Göre Dă̆gllımları

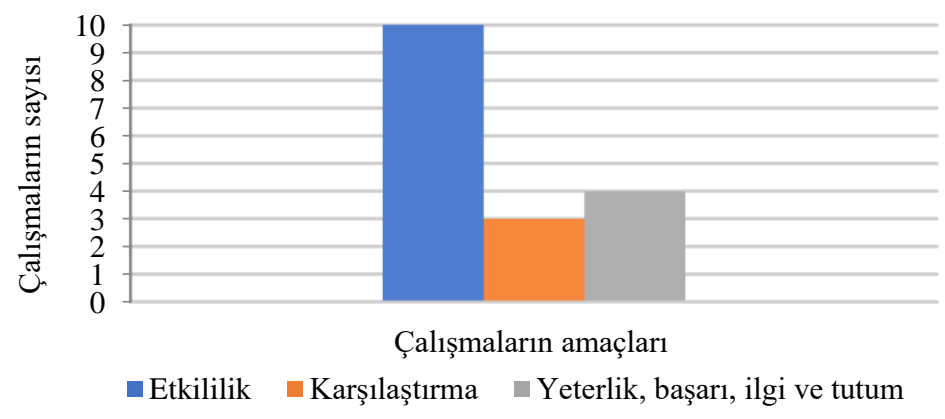


Tablo 1

Zihin Yetersizliği Olan Öğrencilere Fen Öğretimine İlişkin Türkiye’de Yapılan Çalıșmalar

\begin{tabular}{|c|c|c|c|c|c|c|c|c|c|}
\hline Yazar ve yıl & Çalışmanın amacı & $\begin{array}{c}\text { Çalışmanın } \\
\text { yöntemi }\end{array}$ & $\begin{array}{c}\text { Katılımcılar ve } \\
\text { özellikleri }\end{array}$ & Fen konu alanı & Müdahale & $\begin{array}{c}\text { Müdahale } \\
\text { süresi }\end{array}$ & $\begin{array}{c}\text { Veri toplama } \\
\text { arac1 }\end{array}$ & $\begin{array}{c}\text { Geçerlik ve } \\
\text { güvenirlik }\end{array}$ & Bulgular \\
\hline $\begin{array}{l}\text { Demircioğlu } \\
\text { ve Kavgac1, } \\
2020\end{array}$ & $\begin{array}{l}\text { Bu çalışmanın amacı, fen } \\
\text { bilimleri dersi öğretim } \\
\text { programındaki } \\
\text { çevremizdeki ışı ve sesleri } \\
\text { bilir amacına yönelik zihin } \\
\text { yetersizliğine sahip } \\
\text { öğrencilerin doğal ve yapay } \\
\text { sesleri kaynağıyla } \\
\text { ilişkilendirme düzeylerini } \\
\text { belirlemektir. }\end{array}$ & $\begin{array}{l}\text { Nitel araştırma } \\
\text { yöntemlerinden } \\
\text { durum çalışması }\end{array}$ & $\begin{array}{l}\text { Bu çalışmaya } \\
\text { anasınıfı, } \\
\text { ortaokul, özel } \\
\text { eğitim uygulama } \\
\text { okulunda } \\
\text { öğrenim gören } \\
11 \text { erkek } 4 \text { kadın } \\
\text { olmak üzere } 15 \\
\text { zihin yetersizliği } \\
\text { olan öğrenci } \\
\text { katılmıştır. }\end{array}$ & $\begin{array}{l}\text { Doğal ve } \\
\text { yapay ses } \\
\text { kaynakları }\end{array}$ & $\begin{array}{l}\text { Görsel ve } \\
\text { işitsel } \\
\text { ipucu }\end{array}$ & Belirtilmemiş & $\begin{array}{c}\text { Davranış } \\
\text { kontrol } \\
\text { listesi }\end{array}$ & Belirtilmemiş & $\begin{array}{l}\text { Çalışma sonucunda zihin } \\
\text { yetersizliğine sahip öğrencilerin, } \\
\text { sunulan görsel ve işitsel } \\
\text { ipuçlarıyla, günlük hayatlarında } \\
\text { karşışaştı̆ı sesleri, daha iyi } \\
\text { algıladıkları ve ayırt ettikleri, } \\
\text { buna karşın günlük hayatlarında } \\
\text { karş1laşmadıkları sesleri tanımada } \\
\text { güçlük çektikleri tespit edilmiştir. } \\
\text { Ayrıca bazı öğrencilerin sesleri } \\
\text { telaffuz ederken zorlandıkları } \\
\text { belirlenmiştir. }\end{array}$ \\
\hline $\begin{array}{l}\text { Türker ve } \\
\text { Çifci- } \\
\text { Tekinarslan, } \\
2020\end{array}$ & $\begin{array}{l}\text { Bu çalışmada, zihin } \\
\text { yetersizliği olan bir } \\
\text { öğrenciye "besinlerin } \\
\text { sindirimi” konusunun } \\
\text { öğretiminde, doğrudan } \\
\text { öğretim yöntemiyle birlikte } \\
\text { tanılayıcı dallanmış ağaç } \\
\text { tekniğinin yer aldığ } \\
\text { öğretim planı ile aynı } \\
\text { öğrenciye "vücudumuzda } \\
\text { boşaltım" konusunun } \\
\text { öğretiminde, sadece } \\
\text { doğrudan öğretim } \\
\text { yönteminin yer aldığı } \\
\text { öğretim planının etkililiğini } \\
\text { karşlaştırmak } \\
\text { amaçlanmıştır. }\end{array}$ & $\begin{array}{l}\text { Tek denekli } \\
\text { araştırma } \\
\text { yöntemlerinden } \\
\text { uyarlamalı } \\
\text { dönüşümlü } \\
\text { uygulamalar } \\
\text { modeli }\end{array}$ & $\begin{array}{l}\text { Bu çalışmaya } 5 . \\
\text { sınıf } \\
\text { düzeyindeki, } \\
\text { zihin yetersizliği } \\
\text { olan 1 kadın } \\
\text { öğrenci } \\
\text { katılmıştır. }\end{array}$ & $\begin{array}{l}\text { Besinlerin } \\
\text { sindirimi ve } \\
\text { vücudumuzda } \\
\text { boşaltım }\end{array}$ & $\begin{array}{l}\text { Doğrudan } \\
\text { öğretim } \\
\text { yöntemi } \\
\text { ile sunulan } \\
\text { tanılayıcı } \\
\text { dallanmış } \\
\text { ağaç }\end{array}$ & $\begin{array}{l}2 \text { hafta, } \\
\text { toplam } 10 \\
\text { oturum, her } \\
\text { bir oturum } \\
\text { yaklaşık } 28 \\
\text { dk }\end{array}$ & $\begin{array}{l}\text { Başarı testi, } \\
\text { ölçüt } \\
\text { bağımlı ölçü } \\
\text { araçları ve } \\
\text { tanılayıcı } \\
\text { dallanmış } \\
\text { ağaç }\end{array}$ & $\begin{array}{l}\text { Gözlemciler } \\
\text { aras1 } \\
\text { güvenirlik, } \\
\text { uygulama } \\
\text { güvenirliği, } \\
\text { sosyal } \\
\text { geçerlik }\end{array}$ & $\begin{array}{l}\text { Elde edilen sonuçlardan her iki } \\
\text { öğretim planının uygulanması } \\
\text { arasında etkililik açısından bir } \\
\text { farklılık olmadı̈̆ görülmüştür. } \\
\text { Ancak doğrudan öğretim } \\
\text { yöntemiyle birlikte tanılayıcı } \\
\text { dallanmış ağaç tekniğinin } \\
\text { kullanıldı̆̆ öğretim planının } \\
\text { uygulanmasının, sadece doğrudan } \\
\text { öğretim yönteminin kullanıldığı } \\
\text { öğretim planının uygulanmasına } \\
\text { göre daha verimli olduğu } \\
\text { belirlenmiştir. }\end{array}$ \\
\hline
\end{tabular}


Tablo 1 (devami)

\begin{tabular}{|c|c|c|c|c|c|c|c|c|c|}
\hline Yazar ve y1l & Çalışmanın amacı & $\begin{array}{c}\text { Çalışmanın } \\
\text { yöntemi }\end{array}$ & $\begin{array}{c}\text { Katılımcilar ve } \\
\text { özellikleri }\end{array}$ & Fen konu alanı & Müdahale & $\begin{array}{l}\text { Müdahale } \\
\text { süresi }\end{array}$ & $\begin{array}{c}\text { Veri toplama } \\
\text { arac1 }\end{array}$ & $\begin{array}{l}\text { Geçerlik ve } \\
\text { güvenirlik }\end{array}$ & Bulgular \\
\hline $\begin{array}{l}\text { Mete ve } \\
\text { Y1ldırım, } \\
2020\end{array}$ & $\begin{array}{l}\text { Bu çalışmanın amacı, zihin } \\
\text { yetersizliği olan } \\
\text { öğrencilere "sert- } \\
\text { yumuşak" kavramlarının } \\
\text { öğretiminde, doğrudan } \\
\text { öğretim yönteminin } \\
\text { öğrenci başarısı üzerindeki } \\
\text { etkisinin incelenmesidir. }\end{array}$ & $\begin{array}{l}\text { Nitel araştırma } \\
\text { yöntemlerinden } \\
\text { durum çalışması }\end{array}$ & $\begin{array}{l}\text { Bu çalışmaya 6-7. } \\
\text { sinıf } \\
\text { düzeyindeki, } 1 \\
\text { erkek } 2 \text { kadın } \\
\text { olmak üzere } 3 \text {, } \\
\text { zihin yetersizliği } \\
\text { olan öğrenci } \\
\text { katılmışır. }\end{array}$ & $\begin{array}{l}\text { Maddenin sert- } \\
\text { yumuşak } \\
\text { özellikleri }\end{array}$ & $\begin{array}{l}\text { Doğrudan } \\
\text { öğretim } \\
\text { yöntemi }\end{array}$ & $\begin{array}{l}5 \text { hafta, } \\
\text { toplam } 91 \\
\text { oturum }\end{array}$ & $\begin{array}{c}\text { Davranış } \\
\text { kontrol } \\
\text { listesi }\end{array}$ & $\begin{array}{l}\text { Uzman } \\
\text { incelemesi, } \\
\text { tutarlık } \\
\text { incelemesi, } \\
\text { teyit } \\
\text { incelemesi, } \\
\text { veri } \\
\text { çeşitlemesi }\end{array}$ & $\begin{array}{l}\text { Bu çalışmada, her bir sert ve } \\
\text { yumuşak madde, gerçek nesne ve } \\
\text { bu nesnelerin iki boyutlu } \\
\text { temsilleri kullanılarak doğrudan } \\
\text { öğretim yöntemiyle öğretilmiş } \\
\text { olup sonucunda, öğrencilerden } \\
\text { ikisinin "sert-yumuşak" } \\
\text { kavramları öğrendiği, bir } \\
\text { ögrencinin öğrenemediği } \\
\text { belirlenmiştir. }\end{array}$ \\
\hline $\begin{array}{l}\text { Karabulut, } \\
2020\end{array}$ & $\begin{array}{l}\text { Çalışmanın amacı, zihin } \\
\text { yetersizliği olan } \\
\text { öğrencilere fen konularının } \\
\text { kazandırılmasında } \\
\text { doğrudan öğretim } \\
\text { yönteminin tabletli ve } \\
\text { tabletsiz sunumunun } \\
\text { etkililik ve verimlilik } \\
\text { açısından farklılaşıp } \\
\text { farklılaşmadığını } \\
\text { belirlemektir. }\end{array}$ & $\begin{array}{l}\text { Tek denekli } \\
\text { araştırma } \\
\text { yöntemlerinden } \\
\text { uyarlamalı } \\
\text { dönüşümlü } \\
\text { uygulamalar } \\
\text { modeli }\end{array}$ & $\begin{array}{l}\text { Bu çalışmaya } \\
\text { ortaokul } \\
\text { düzeyinde } \\
\text { öğrenim gören, } 4 \\
\text { erkek zihin } \\
\text { yetersizliği olan } \\
\text { öğrenci } \\
\text { katılmıştır. }\end{array}$ & $\begin{array}{l}\text { Sindirim } \\
\text { sistemi ve } \\
\text { solunum } \\
\text { sistemi }\end{array}$ & $\begin{array}{l}\text { Doğrudan } \\
\text { öğretim } \\
\text { yönteminin } \\
\text { tabletli } \\
\text { sunumu }\end{array}$ & $\begin{array}{l}1 \text { hafta, } \\
\text { toplam } 65 \\
\text { oturum, her } \\
\text { bir oturum } \\
\text { yaklaşık } 90 \\
\text { dk }\end{array}$ & $\begin{array}{l}\text { Ölçüt bağımlı } \\
\text { ölçü araçları }\end{array}$ & $\begin{array}{l}\text { Gözlemciler- } \\
\text { aras1 } \\
\text { güvenirlik, } \\
\text { uygulama } \\
\text { güvenirliği, } \\
\text { sosyal } \\
\text { geçerlik }\end{array}$ & $\begin{array}{l}\text { Çalışmadan elde edilen } \\
\text { sonuçlardan, doğrudan öğretim } \\
\text { yönteminin tabletli ve tabletsiz } \\
\text { sunumunun etkililik, verimlilik ve } \\
\text { kalıcılık açısından farklılık } \\
\text { göstermediği görülmüştür. }\end{array}$ \\
\hline $\begin{array}{l}\text { Çıkılli-Soylu } \\
\text { vd., } 2019\end{array}$ & $\begin{array}{l}\text { Bu çalışmanın amacı, hafif } \\
\text { düzey zihin yetersizliği } \\
\text { olan öğrencilere fen } \\
\text { konularının (iskelet ve } \\
\text { solunum sistemi) } \\
\text { kazandırılması ve } \\
\text { kalıcılığının } \\
\text { sağlanmasında, doğrudan } \\
\text { öğretim yöntemi ve } \\
\text { şematik düzenleyici ile } \\
\text { hazırlanan öğretim } \\
\text { programlarının } \\
\text { etkililiğinin } \\
\text { belirlenmesidir. }\end{array}$ & $\begin{array}{l}\text { Tek denekli } \\
\text { araştırma } \\
\text { yöntemlerinden } \\
\text { uyarlamalı } \\
\text { dönüşümlü } \\
\text { uygulamalar } \\
\text { modeli }\end{array}$ & $\begin{array}{l}\text { Bu çalışmaya } \\
\text { ortaokul } \\
\text { düzeyinde } \\
\text { öğrenim gören, } \\
\text { zihin yetersizliği } \\
\text { olan 1 erkek 1 } \\
\text { kadın olmak } \\
\text { üzere } 2 \text { öğrenci } \\
\text { katılmıştır. }\end{array}$ & $\begin{array}{l}\text { İskelet ve } \\
\text { solunum } \\
\text { sistemi }\end{array}$ & $\begin{array}{l}\text { Doğrudan } \\
\text { öğretim } \\
\text { yöntemi ve } \\
\text { şematik } \\
\text { düzenleyici }\end{array}$ & $\begin{array}{l}3 \text { gün, toplam } \\
12 \text { oturum, } \\
\text { her oturum } \\
\text { yaklaşık } 25 \mathrm{dk}\end{array}$ & $\begin{array}{l}\text { Ölçüt bağımlı } \\
\text { ölçü aracı }\end{array}$ & $\begin{array}{l}\text { Gözlemciler- } \\
\text { arası } \\
\text { güvenirlik, } \\
\text { uygulama } \\
\text { güvenirliği }\end{array}$ & $\begin{array}{l}\text { Her iki denek de doğrudan öğretim } \\
\text { yöntemi ve şematik düzenleyici } \\
\text { ile hazırlanan öğretim planı ile } \\
\text { fen konularını kazanmış olup } \\
\text { şematik düzenleyici ile doğrudan } \\
\text { öğretim yönteminin etkililik ve } \\
\text { kalıcılık açısından farklılaşmadığı } \\
\text { görülmüş̧ür. }\end{array}$ \\
\hline
\end{tabular}


Tablo 1 (devami)

\begin{tabular}{|c|c|c|c|c|c|c|c|c|c|}
\hline Yazar ve y1l & Çalışmanın amacı & $\begin{array}{c}\text { Çalışmanın } \\
\text { yöntemi }\end{array}$ & $\begin{array}{l}\text { Katılımcilar ve } \\
\text { özellikleri }\end{array}$ & Fen konu alanı & Müdahale & $\begin{array}{l}\text { Müdahale } \\
\text { süresi }\end{array}$ & $\begin{array}{c}\text { Veri toplama } \\
\text { arac1 }\end{array}$ & $\begin{array}{c}\text { Geçerlik ve } \\
\text { güvenirlik }\end{array}$ & Bulgular \\
\hline Karasu, 2019 & $\begin{array}{l}\text { Bu çalışma; hafif düzey zihin } \\
\text { yetersizliği olan özel eğitim } \\
\text { sınıfı öğrencilerine, duyu } \\
\text { organları konusunun 5E } \\
\text { yöntemi ile öğretiminin } \\
\text { etkililiğini ortaya koymak } \\
\text { amacıyla yapılmıştır. }\end{array}$ & $\begin{array}{l}\text { Nitel araştırma } \\
\text { yöntemlerinden } \\
\text { durum çalışmas }\end{array}$ & $\begin{array}{l}\text { Bu çalışmaya } 4 . \\
\text { sınıf ve lise } \\
\text { düzeyinde olup } \\
\text { ayrıca özel } \\
\text { eğitim } \\
\text { rehabilitasyon } \\
\text { merkezinde } \\
\text { öğrenim gören, } \\
\text { zihin yetersizliği } \\
\text { olan } 3 \text { erkek } \\
\text { öğrenci } \\
\text { katılmıştır. }\end{array}$ & Duyu organları & 5E yöntemi & $\begin{array}{l}2 \text { gün, toplam } \\
2 \text { oturum, } \\
\text { her bir } \\
\text { oturum } \\
\text { yaklaşık } \\
\text { olarak } 80 \\
\text { dk. }\end{array}$ & $\begin{array}{c}\text { Davranış } \\
\text { kontrol } \\
\text { listesi }\end{array}$ & Belirtilmemiş & $\begin{array}{l}\text { Çalışmanın sonucunda, duyu } \\
\text { organları konusunun } \\
\text { öğretiminde } 5 \mathrm{E} \text { yönteminin } \\
\text { etkili olduğu ortaya } \\
\text { çıarılmıştır. }\end{array}$ \\
\hline Tosun, 2019 & $\begin{array}{l}\text { Bu çalışmada, hafif düzey } \\
\text { zihin yetersizliği olan } \\
\text { öğrencilere, fen bilimleri } \\
\text { dersinde uygulanan } \\
\text { basitleştirilmiş STEM } \\
\text { eğitiminin, ögrencilerin } \\
\text { derse olan katılım düzeyi ile } \\
\text { fene yönelik ilgi ve } \\
\text { tutumları üzerinde sağladığ } \\
\text { değişimin incelenmesi } \\
\text { amaçlanmıştır. }\end{array}$ & $\begin{array}{l}\text { Nitel araştırma } \\
\text { yöntemlerinden } \\
\text { durum çalışmas } 1\end{array}$ & $\begin{array}{l}\text { Bu çalışmaya } 8 . \\
\text { sınıf } \\
\text { düzeyindeki, } 5 \\
\text { erkek } 1 \text { kadın } \\
\text { olmak üzere } 6 \\
\text { zihin yetersizliği } \\
\text { olan öğrenci } \\
\text { katılmıştır. }\end{array}$ & $\begin{array}{l}\text { Kuvvetin } \\
\text { etkisi, } \\
\text { miknatısın } \\
\text { etkisi, } \\
\text { geçmişten } \\
\text { günümüze ses } \\
\text { teknolojileri } \\
\text { ve gürülttü } \\
\text { kirliliği }\end{array}$ & $\begin{array}{l}\text { STEM } \\
\text { eğitimi }\end{array}$ & $\begin{array}{l}18 \text { hafta, } \\
\text { toplam } 36 \\
\text { oturum }\end{array}$ & $\begin{array}{l}\text { Davranış } \\
\text { kontrol } \\
\text { listesi, ölçüt } \\
\text { bağımlı ölçü } \\
\text { aracı, başarı } \\
\text { testi }\end{array}$ & $\begin{array}{l}\text { Gözlemciler- } \\
\text { arası } \\
\text { güvenirlik, } \\
\text { uygulama } \\
\text { güvenirliği }\end{array}$ & $\begin{array}{l}\text { Çalışmanın sonucunda } \\
\text { ögrencilerde, fen dersine yönelik } \\
\text { katılımın arttı̆̆ı, ilgi düzeyinin } \\
\text { yükseldiği ve öğrencilerin fen } \\
\text { bilimleri dersine yönelik pozitif } \\
\text { tutum sergiledikleri } \\
\text { gözlemlenmiştir. }\end{array}$ \\
\hline $\begin{array}{l}\text { Yikmış ve } \\
\text { Varol- } \\
\text { Özçakır, } \\
2019\end{array}$ & $\begin{array}{l}\text { Bu çalışmada hafif düzey } \\
\text { zihin yetersizliği olan iki } \\
\text { öğrenciye, hayvanların } \\
\text { yararları, beslenme şekilleri } \\
\text { ve barınakları konularının } \\
\text { kazandırılmasında, } \\
\text { doğrudan öğretim } \\
\text { yöntemiyle sunulan kavram } \\
\text { haritası tekniğinin etkililiği } \\
\text { incelenmiștir. }\end{array}$ & $\begin{array}{l}\text { Tek denekli } \\
\text { araştırma } \\
\text { yöntemlerinden } \\
\text { yoklama evreli } \\
\text { çoklu yoklama } \\
\text { modeli }\end{array}$ & $\begin{array}{l}\text { Bu çalışmaya } \\
\text { ortaokul } \\
\text { düzeyinde } \\
\text { öğrenim gören, } \\
\text { zihin yetersizliği } \\
\text { olan } 2 \text { erkek } \\
\text { öğrenci } \\
\text { katılmıştır. }\end{array}$ & $\begin{array}{l}\text { Hayvanların } \\
\text { yararları, } \\
\text { beslenme } \\
\text { şekilleri ve } \\
\text { barınakları }\end{array}$ & $\begin{array}{l}\text { Doğrudan } \\
\text { öğretim } \\
\text { yöntemi ile } \\
\text { sunulan } \\
\text { kavram } \\
\text { haritas1 }\end{array}$ & $\begin{array}{l}12 \text { hafta, } \\
\text { toplam } 12 \\
\text { oturum, her } \\
\text { bir oturum } \\
\text { yaklaşık } 28 \\
\text { dk. }\end{array}$ & $\begin{array}{l}\text { Ölçüt bağımlı } \\
\text { ölçü aracı, } \\
\text { davranış } \\
\text { kontrol } \\
\text { listesi, } \\
\text { kavram } \\
\text { haritas1 }\end{array}$ & $\begin{array}{l}\text { Gözlemciler- } \\
\text { arası } \\
\text { güvenirlik, } \\
\text { uygulama } \\
\text { güvenirliği, } \\
\text { sosyal } \\
\text { geçerlik }\end{array}$ & $\begin{array}{l}\text { Çalışmanın sonucunda, hafif } \\
\text { zihin yetersizliği gösteren } \\
\text { öğrencilere, hayvanların } \\
\text { yararları, beslenme şekilleri ve } \\
\text { barınakları konularının } \\
\text { kazandırılmasında, doğrudan } \\
\text { ögretim yöntemiyle sunulan } \\
\text { kavram haritası tekniğinin etkili } \\
\text { olduğu görülmüş̧ür. }\end{array}$ \\
\hline
\end{tabular}


Tablo 1 (devami)

\begin{tabular}{|c|c|c|c|c|c|c|c|c|c|}
\hline Yazar ve yil & Çalışmanın amacı & $\begin{array}{c}\text { Çalışmanın } \\
\text { yöntemi }\end{array}$ & $\begin{array}{c}\text { Katılimcilar ve } \\
\text { özellikleri }\end{array}$ & Fen konu alanı & Müdahale & $\begin{array}{l}\text { Müdahale } \\
\text { süresi }\end{array}$ & $\begin{array}{c}\text { Veri toplama } \\
\text { aracı }\end{array}$ & $\begin{array}{l}\text { Geçerlik ve } \\
\text { güvenirlik }\end{array}$ & Bulgular \\
\hline Öner, 2018 & $\begin{array}{l}\text { Bu çalışmada, hafif düzey } \\
\text { zihin yetersizliği gösteren } \\
\text { öğrencilere, fen bilimleri } \\
\text { dersinde canlıların ve } \\
\text { bitkilerin sinıflandırılması } \\
\text { konusunun öğretiminde, } \\
\text { bilgisayar destekli öğretim } \\
\text { yönteminin etkililik ve } \\
\text { verimliliği araştırılmıştır. }\end{array}$ & $\begin{array}{l}\text { Tek denekli } \\
\text { araştırma } \\
\text { yöntemlerinden } \\
\text { yoklama evreli } \\
\text { çoklu yoklama } \\
\text { modeli }\end{array}$ & $\begin{array}{l}\text { Bu çalışmaya } 5 . \\
\text { sinıf } \\
\text { düzeyindeki, } \\
\text { zihin yetersizliğ } \\
\text { olan } 2 \text { erkek } 1 \\
\text { kadın olmak } \\
\text { üzere } 3 \text { öğrenci } \\
\text { katılmıştır. }\end{array}$ & $\begin{array}{l}\text { Canlıların ve } \\
\text { bitkilerin } \\
\text { sinıflandırılmas1 }\end{array}$ & $\begin{array}{l}\text { Bilgisayar } \\
\text { destekli } \\
\text { öğretim }\end{array}$ & $\begin{array}{l}\text { Toplam } 18 \\
\text { oturum, her } \\
\text { bir oturum } \\
40 \mathrm{dk} \text {. }\end{array}$ & Başarı testi & Belirtilmemiş & $\begin{array}{l}\text { Çalışmanın bulgularına dayanarak, } \\
\text { fen bilimleri dersinde canlıların } \\
\text { ve bitkilerin sınıflandırılması } \\
\text { konusunun öğretiminde tüm } \\
\text { denekler için bilgisayar destekli } \\
\text { öğretimin etkili olduğu ortaya } \\
\text { çıkmıştır. }\end{array}$ \\
\hline $\begin{array}{l}\text { Yozgat vd., } \\
2018\end{array}$ & $\begin{array}{l}\text { Bu çalışmanın amacı hafif } \\
\text { düzeyde zihinsel } \\
\text { yetersizliğe sahip } \\
\text { kaynaştırma ögrencilerine } \\
\text { elementlerin isimlerini } \\
\text { öğretiminde doğrudan } \\
\text { öğretim yönteminin } \\
\text { etkililiğini incelemektir }\end{array}$ & $\begin{array}{l}\text { Tek denekli } \\
\text { araştırma } \\
\text { yöntemlerinden } \\
\text { denekler arası } \\
\text { çoklu yoklama } \\
\text { modeli }\end{array}$ & $\begin{array}{l}\text { Bu çalışmaya } \\
\text { ortaokul } \\
\text { düzeyinde } \\
\text { öğrenim gören, } 1 \\
\text { kadın, } 3 \text { erkek } \\
\text { olmak üzere } 4 \\
\text { zihin yetersizliği } \\
\text { olan öğrenci } \\
\text { katılmıştır. }\end{array}$ & $\begin{array}{l}\text { Elementlerin } \\
\text { isimleri }\end{array}$ & $\begin{array}{l}\text { Doğrudan } \\
\text { öğretim } \\
\text { yöntemi }\end{array}$ & $\begin{array}{l}\text { Toplam } 60 \\
\text { oturum }\end{array}$ & $\begin{array}{l}\text { Ölçüt bağımlı } \\
\text { ölçü araçları, } \\
\text { çalışma } \\
\text { kağıtları }\end{array}$ & $\begin{array}{l}\text { Gözlemciler- } \\
\text { arası } \\
\text { güvenirlik, } \\
\text { uygulama } \\
\text { güvenirliği }\end{array}$ & $\begin{array}{l}\text { Çalışmanın sonucunda, } \\
\text { kaynaştırma öğrencilerine fen } \\
\text { bilgisi öğretiminde doğrudan } \\
\text { öğretim yönteminin etkili olduğu } \\
\text { ortaya çıarılmıştır. }\end{array}$ \\
\hline Çapraz, 2016 & $\begin{array}{l}\text { Bu çalışmada, ortaokul özel } \\
\text { alt sınıfta öğrenim gören } \\
\text { zihin yetersizliği gösteren } \\
\text { öğrencilere, doğrudan } \\
\text { öğretim yöntemiyle bazı } \\
\text { maddelerin "katı-sıvı-gaz" } \\
\text { hallerinin öğretiminin, } \\
\text { etkililiği ve bu yöntemin } \\
\text { kullanışl1lı̆̆ının tespit } \\
\text { edilmesi amaçlanmıştır. }\end{array}$ & $\begin{array}{l}\text { Nitel araştırma } \\
\text { yöntemlerinden } \\
\text { durum çalışması }\end{array}$ & $\begin{array}{l}\text { Bu çalışmaya 5-6. } \\
\text { sinıf } \\
\text { düzeyindeki, } \\
\text { zihin yetersizliği } \\
\text { olan } 3 \text { erkek } 1 \\
\text { kadın olmak } \\
\text { üzere } 4 \text { öğrenci } \\
\text { katılmıştır. }\end{array}$ & $\begin{array}{l}\text { Maddelerin "kat1- } \\
\text { sivi-gaz" } \\
\text { halleri }\end{array}$ & $\begin{array}{l}\text { Doğrudan } \\
\text { ögrretim } \\
\text { yöntemi }\end{array}$ & $\begin{array}{l}11 \text { hafta, } \\
\text { toplam } 96 \\
\text { oturum, her } \\
\text { bir oturum } 40 \\
\text { dk. }\end{array}$ & $\begin{array}{l}\text { Davranış } \\
\text { kontrol } \\
\text { listesi }\end{array}$ & Belirtilmemiş & $\begin{array}{l}\text { Bu çalışmada, her bir katı, sıvı ve } \\
\text { gaz madde, gerçek nesne ve bu } \\
\text { nesnelerin iki boyutlu temsilleri } \\
\text { kullanılarak doğrudan öğretim } \\
\text { yöntemiyle öğretilmiş olup } \\
\text { çalısmanın sonucunda, doğrudan } \\
\text { öğretim yönteminin zihin } \\
\text { yetersizliği olan öğrencilere, bazı } \\
\text { maddelerin "kat1-sıv1-gaz" } \\
\text { hallerinin öğretiminde, etkili bir } \\
\text { yöntem olduğunu ortaya } \\
\text { koyulmuştur. Ayrıca bu } \\
\text { yöntemin, öğrencilerde kalıcılı̆̆ı } \\
\text { sağladığı ve akademik başarıyı } \\
\text { artırdığı görülmüștür. }\end{array}$ \\
\hline
\end{tabular}


Tablo 1 (devami)

\begin{tabular}{|c|c|c|c|c|c|c|c|c|c|}
\hline Yazar ve y1l & Çalışmanın amacı & $\begin{array}{c}\text { Çalışmanın } \\
\text { yöntemi }\end{array}$ & $\begin{array}{c}\text { Katılimcilar ve } \\
\text { özellikleri }\end{array}$ & Fen konu alanı & Müdahale & $\begin{array}{l}\text { Müdahale } \\
\text { süresi }\end{array}$ & $\begin{array}{c}\text { Veri toplama } \\
\text { araci }\end{array}$ & $\begin{array}{l}\text { Geçerlik ve } \\
\text { güvenirlik }\end{array}$ & Bulgular \\
\hline Çevik, 2016 & $\begin{array}{l}\text { Bu çalışmanın amacı, fen } \\
\text { bilimleri dersinde proje } \\
\text { tabanlı ögrenme } \\
\text { yaklaşımının (PTÖY), } \\
\text { ilkokul 4. sınıfta öğrenim } \\
\text { görmekte olan, hafif } \\
\text { düzeyde zihin yetersizliği } \\
\text { gösteren öğrencilerin, } \\
\text { akademik başarılarına ve } \\
\text { tutumlarına etkisini tespit } \\
\text { etmektir. }\end{array}$ & $\begin{array}{l}\text { Nicel araştırma } \\
\text { yöntemlerinden } \\
\text { tek grup ön test } \\
\text { son test desen }\end{array}$ & $\begin{array}{l}\text { Bu çalışmaya } 4 . \\
\text { sınıf } \\
\text { düzeyindeki, } 4 \\
\text { erkek } 4 \text { kadın } \\
\text { olmak üzere } 8 \\
\text { zihin yetersizliği } \\
\text { olan öğrenci } \\
\text { katılmışır. }\end{array}$ & $\begin{array}{l}\text { İnsan ve çevre } \\
\text { ilişkisi konusu }\end{array}$ & $\begin{array}{l}\text { Proje } \\
\text { tabanlı } \\
\text { öğrenme } \\
\text { yaklaşım1 } \\
\text { (PTÖY) }\end{array}$ & Belirtilmemiş & $\begin{array}{l}\text { Başarı testi, } \\
\text { tutum ölçeği, } \\
\text { görüşme } \\
\text { formu }\end{array}$ & $\begin{array}{l}\text { Cronbach } \\
\text { alfa, madde } \\
\text { güçlüğ̈̈, } \\
\text { madde ayırt } \\
\text { ediciliği, } \\
\text { yap1 } \\
\text { geçerliği, } \\
\text { kapsam } \\
\text { geçerliği, } \\
\text { kodlama } \\
\text { güvenirliği }\end{array}$ & $\begin{array}{l}\text { Çalışma sonunda PTÖY ile işlenen } \\
\text { dersin fen bilimleri dersinde } \\
\text { akademik başarıyı anlamlı } \\
\text { düzeyde artırdığı ve derse olan } \\
\text { tutumu olumlu yönde etkilediği } \\
\text { söylenebilir. }\end{array}$ \\
\hline Кауа, 2016 & $\begin{array}{l}\text { Bu çalışmanın amacı hafif } \\
\text { düzeyde zihin yetersizliği } \\
\text { gösteren öğrencilere canlı- } \\
\text { cansız kavramının } \\
\text { öğretiminde sabit bekleme } \\
\text { süreli öğretim yönteminin } \\
\text { (SBSÖY) etkililiğini } \\
\text { incelemektir. }\end{array}$ & $\begin{array}{l}\text { Tek denekli } \\
\text { araştırma } \\
\text { yöntemlerinden } \\
\text { yoklama evreli } \\
\text { çoklu yoklama } \\
\text { modeli }\end{array}$ & $\begin{array}{l}\text { Bu çalışmaya } \\
\text { zihin yetersizliği } \\
\text { olan } 3 . \text { sınıf } \\
\text { düzeyinde } 3 \\
\text { erkek öğrenci } \\
\text { katılmıştır. }\end{array}$ & $\begin{array}{c}\text { Canl1-cansız } \\
\text { kavramının } \\
\text { öğretimi }\end{array}$ & $\begin{array}{l}\text { Sabit } \\
\text { bekleme } \\
\text { süreli } \\
\text { öğretim } \\
\text { yöntemi }\end{array}$ & $\begin{array}{l}4 \text { hafta, } \\
\text { toplam } 11 \\
\text { oturum }\end{array}$ & $\begin{array}{c}\text { Davranış } \\
\text { kontrol } \\
\text { listesi }\end{array}$ & $\begin{array}{l}\text { Uygulama } \\
\text { güvenirliği }\end{array}$ & $\begin{array}{l}\text { Çalışmanın sonucunda SBSÖY'nin } \\
\text { ilkokul özel eğitim sınıfında yer } \\
\text { alan ve hafif düzeyde zihin } \\
\text { yetersizliği olan öğrencilere canlı- } \\
\text { cansız kavramının öğretiminde } \\
\text { etkili olduğu görülmüştür. }\end{array}$ \\
\hline $\begin{array}{l}\text { Sola-Özgüç } \\
\text { ve } \\
\text { Cavkaytar, } \\
2016\end{array}$ & $\begin{array}{l}\text { Bu çalışmanın amacı; zihin } \\
\text { yetersizliği olan öğrencilere } \\
\text { teknoloji destekli öğretim } \\
\text { etkinliklerinin uygulanması } \\
\text { ve bu süreçte ortaya } \\
\text { çıkabilecek sorunların } \\
\text { belirlenerek çözümlenmesi } \\
\text { ve öğrencilerin fen bilimleri } \\
\text { dersindeki öğrenme } \\
\text { yeterliklerinin artırılmasıdır. }\end{array}$ & $\begin{array}{l}\text { Nitel araştırma } \\
\text { yöntemlerinden } \\
\text { eylem } \\
\text { araştırması }\end{array}$ & $\begin{array}{l}\text { Bu çalışmaya } 6 . \\
\text { sinıf } \\
\text { düzeyindeki, } 5 \\
\text { erkek } 6 \text { kadın } \\
\text { olmak üzere } 11 \\
\text { zihin yetersizliği } \\
\text { olan öğrenci } \\
\text { katılmı̧tır. }\end{array}$ & $\begin{array}{l}\text { Madde ve } \\
\text { değişim ünitesi }\end{array}$ & $\begin{array}{l}\text { İleri düzey } \\
\text { teknolojik } \\
\text { araçlar } \\
\text { (tablet } \\
\text { bilgisayar, } \\
\text { etkileşimli } \\
\text { tahta) }\end{array}$ & $\begin{array}{l}12 \text { hafta, } \\
\text { toplam } 48 \\
\text { oturum, her } \\
\text { bir oturum } \\
\text { yaklaşık } 40 \\
\text { dk. }\end{array}$ & $\begin{array}{l}\text { Gözlem } \\
\text { formu, belge } \\
\text { incelemesi, } \\
\text { araştırmac1 } \\
\text { günlüğ̈̈, } \\
\text { davranış } \\
\text { kontrol } \\
\text { listesi, ölçüt } \\
\text { bağımlı test, } \\
\text { toplantı } \\
\text { tutanakları }\end{array}$ & $\begin{array}{l}\text { Uzman } \\
\text { incelemesi, } \\
\text { kodlama } \\
\text { güvenirliği, } \\
\text { veri } \\
\text { çeşitlemesi }\end{array}$ & $\begin{array}{l}\text { Çalışmanın bulguları; teknoloji } \\
\text { destekli öğgretim etkinliklerinin } \\
\text { öğrencilerin fen bilimleri dersi } \\
\text { başarısını arttırdığını göstermiştir. } \\
\text { Bunun yanında öğrencilerin fen } \\
\text { bilimleri dersinde öğrendikleri } \\
\text { bilgileri günlük yaşama } \\
\text { aktarabildikleri ve öğretim } \\
\text { etkinliklerinin öğrenci davranışları } \\
\text { üzerinde de önemli katkıları olduğu } \\
\text { belirlenmiştir. Bu katkılar, } \\
\text { öğrenciler arasında akranlar arası } \\
\text { etkileşimi ve iş birliğini arttırması, } \\
\text { öğrencilerin sorumluluk alma } \\
\text { davranışını geliştirmesi ve } \\
\text { öğrencilerin derse katılımını } \\
\text { arttırması şeklinde sıralanabilir. }\end{array}$ \\
\hline
\end{tabular}


Tablo 1 (devami)

\begin{tabular}{|c|c|c|c|c|c|c|c|c|c|}
\hline Yazar ve y1l & Çalışmanın amacı & $\begin{array}{c}\text { Çalışmanın } \\
\text { yöntemi }\end{array}$ & $\begin{array}{c}\text { Katılımcilar ve } \\
\text { özellikleri }\end{array}$ & Fen konu alanı & Müdahale & $\begin{array}{l}\text { Müdahale } \\
\text { süresi }\end{array}$ & $\begin{array}{c}\text { Veri toplama } \\
\text { arac1 }\end{array}$ & $\begin{array}{l}\text { Geçerlik ve } \\
\text { güvenirlik }\end{array}$ & Bulgular \\
\hline $\begin{array}{l}\text { Tezcan, } \\
2012\end{array}$ & $\begin{array}{l}\text { Bu çalışmanın amacı, zihin } \\
\text { yetersizliği olan } \\
\text { öğrencilerin, matematik ve } \\
\text { fen bilimleri derslerinde } \\
\text { yer alan kavram ve } \\
\text { becerileri, teknoloji desteği } \\
\text { ile etkili bir şekilde } \\
\text { öğrenmesini sağlamaktır. }\end{array}$ & $\begin{array}{l}\text { Nicel araştırma } \\
\text { yöntemlerinden } \\
\text { ön test son test } \\
\text { kontrol gruplu } \\
\text { desen }\end{array}$ & $\begin{array}{l}\text { Bu çalışmaya } \\
\text { ortaokul } \\
\text { düzeyinde } \\
\text { öğrenim gören, } \\
11 \text { erkek 9 } \\
\text { kadın olmak } \\
\text { üzere } 20 \text { zihin } \\
\text { yetersizliği olan } \\
\text { öğrenci } \\
\text { katılmıştır. }\end{array}$ & $\begin{array}{l}\text { Vücudu-muzu } \\
\text { tanıyalım, } \\
\text { maddeyi } \\
\text { tanıyalım, 1şık } \\
\text { ve ses }\end{array}$ & $\begin{array}{l}\text { Web destekli } \\
\text { uzaktan eğitim } \\
\text { sistemi }\end{array}$ & 14 hafta & Başarı testi & Belirtilmemiş & $\begin{array}{l}\text { Çalışmadan elde edilen } \\
\text { sonuçlardan, web destekli } \\
\text { uzaktan eğitim sistemi } \\
\text { kullanılarak sunulan derslerde, } \\
\text { öğrencilerin akademik } \\
\text { başarısının arttı̆̆ ve öğrenmede } \\
\text { kalıc1lı̆̆ın sağlandığı } \\
\text { görülmektedir. }\end{array}$ \\
\hline $\begin{array}{l}\text { Kocadağ } \\
2009\end{array}$ & $\begin{array}{l}\text { Bu çalışma, ilköğretim } 4 . \\
\text { sınıf fen bilimleri dersinde } \\
\text { interaktif eğitim yazılımları } \\
\text { kullanımının, kaynaştırma } \\
\text { öğrencilerinin başarısı ve } \\
\text { kalıcılığına etkisini } \\
\text { incelemek amacıyla } \\
\text { yapılmıştır. }\end{array}$ & $\begin{array}{l}\text { Nicel araştırma } \\
\text { yöntemlerinden } \\
\text { ön test son test } \\
\text { kontrol gruplu } \\
\text { desen }\end{array}$ & $\begin{array}{l}\text { Bu çalışmaya } 4 . \\
\text { sınıf düzeyinde } \\
\text { olan, } 40 \text { zihin } \\
\text { yetersizliği olan } \\
\text { öğrenci } \\
\text { katılmıştır. }\end{array}$ & $\begin{array}{l}\text { Gezegenimiz } \\
\text { ve dünya } \\
\text { ünitesi }\end{array}$ & $\begin{array}{l}\text { Bilgisayar destekli } \\
\text { bir interaktif } \\
\text { eğitim yazılımı }\end{array}$ & Belirtilmemiş & $\begin{array}{l}\text { Ölçüt } \\
\text { bağıılıl } \\
\text { ölçü aracı }\end{array}$ & $\begin{array}{l}\text { Cronbach } \\
\text { alfa }\end{array}$ & $\begin{array}{l}\text { Çalışma sonucunda, son test } \\
\text { verilerine göre deney grubu, } \\
\text { kontrol grubuna nazaran anlamlı } \\
\text { bir başarı elde etmiştir. Bu } \\
\text { sonuca göre, interaktif eğitim } \\
\text { uygulamalarının öğrenci başarısı } \\
\text { üzerinde olumlu etkisi olduğu } \\
\text { söylenebilir. }\end{array}$ \\
\hline Demir, 2008 & $\begin{array}{l}\text { Bu çalışmanın amacı, zihin } \\
\text { yetersizliği gösteren } \\
\text { öğrencilere, sindirim } \\
\text { sistemi organlarının } \\
\text { öğretiminde } \\
\text { basamaklandırılmış } \\
\text { öğretim yöntemine göre } \\
\text { hazırlanan } \\
\text { bireyselleştirilmiş öğretim } \\
\text { materyalinin etkililiğini } \\
\text { belirlemektir. }\end{array}$ & $\begin{array}{l}\text { Tek denekli } \\
\text { araştırma } \\
\text { yöntemlerinden } \\
\text { AB modeli }\end{array}$ & $\begin{array}{l}\text { Bu çalışmaya } \\
\text { özel eğitim ve } \\
\text { rehabilitasyon } \\
\text { merkezinde } \\
\text { öğrenim gören, } \\
\text { zihin } \\
\text { yetersizliği olan } \\
2 \text { öğrenci } \\
\text { katılmıştır. }\end{array}$ & $\begin{array}{l}\text { Sindirim } \\
\text { sistemi } \\
\text { organlar1 }\end{array}$ & $\begin{array}{l}\text { Basamaklandırılmış } \\
\text { öğretim yöntemi }\end{array}$ & $\begin{array}{l}4 \text { hafta, } 50 \\
\text { oturum, her } \\
\text { bir oturum } \\
\text { yaklaşı } 20 \\
\text { dk. }\end{array}$ & $\begin{array}{l}\text { Ölçüt } \\
\text { bağımlı } \\
\text { ölçü aracı }\end{array}$ & Belirtilmemiş & $\begin{array}{l}\text { Çalışmanın bulgularına dayanarak } \\
\text { elde edilen sonuçlara göre, } \\
\text { basamaklandırılmış ögretim } \\
\text { yöntemine göre hazırlanan } \\
\text { bireyselleştirilmişöğretim } \\
\text { materyalinin, sindirim sistemi } \\
\text { organları ögretiminde her } \\
\text { öğrencide etkili olduğu } \\
\text { bulunmuştur. }\end{array}$ \\
\hline
\end{tabular}




\section{Çalışmaların Yöntemine Göre Dağılımları}

Zihin yetersizliği olan öğrencilere fen kavram, bilgi, becerilerin öğretiminde yapılan çalışmaların yöntemlerine göre dağılımları Şekil 3 ’te yer almaktadır. Çalışmaların yöntemi incelendiğinde, sekiz çalışmada tek denekli araștırma yöntemleri kullanılmış olup bu çalışmaların üçünde yoklama evreli çoklu yoklama modeline (Kaya, 2016; Öner, 2018; Yıkmış \& Varol-Özçakır, 2019) yine üçünde uyarlamalı dönüşümlü uygulamalar modeline (Çıkıl1-Soylu vd., 2019; Karabulut, 2020; Türker \& Çifci-Tekinarslan, 2020), birinde AB modeline (Demir, 2008) ve yine birinde yoklama denemeli çoklu yoklama modeline (Yozgat vd., 2018) yer verilmiştir. Çalışmaların altısında nitel araştırma yöntemleri kullanılmış olup bu çalışmaların beşinde durum çalışmasına (Çapraz, 2016; Demircioğlu \& Kavgac1, 2020; Karasu, 2019; Mete \& Y1ldırım, 2020; Tosun, 2019), birinde ise eylem araştırmasına (Sola-Özgüç \& Cavkaytar, 2016) yer verilmiştir. Çalışmaların üçünde ise nicel araştırma yöntemleri kullanılmış olup bu çalışmaların ikisinde ön test son test kontrol gruplu desene (Kocadağ, 2009; Tezcan, 2012), birinde ise tek grup ön test son test desene (Çevik, 2016) yer verilmiştir.

\section{Şekil 3}

Zihin Yetersizliği Olan Öğrencilere Fen Kavram, Bilgi, Becerilerin Öğretiminde Yapılan Çalışmaların Yöntemlerine Göre Dă̆llımları

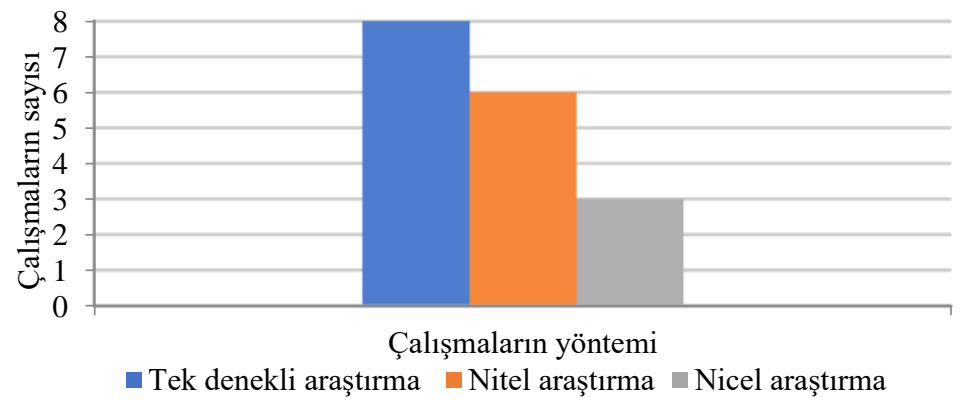

\section{Çalışmaların Katılımcıları ve Özelliklerine Göre Dağıımları}

Zihin yetersizliği olan öğrencilere sınıf düzeylerine göre dağılımları Şekil 4'te yer almaktadır. Çalışmaların katılımcıları ve özelliklerine yönelik, incelenen 17 çalışmada toplam 131 katılımcının yer aldığı ve bu katılımcıların 58'inin erkek, 31'inin kadın olduğu görülmüştür. Ayrıca iki çalışmada (Demir, 2008; Kocadağ, 2009) ise katılımcıların cinsiyeti belirtilmemiştir. Çalışmalarda katılımcıların öğrenim gördükleri sınıf düzeyleri de incelenmiş olup çalışmaların 12'sinde ortaokul (Çapraz, 2016; Çıkıl1-Soylu vd., 2019; Demircioğlu \& Kavgacı, 2020; Karabulut, 2020; Mete \& Yıldırım, 2020; Öner, 2018; Sola-Özgüç \& Cavkaytar, 2016; Tezcan, 2012; Tosun, 2019; Türker \& Çifci-Tekinarslan, 2020; Yıkmış \& Varol-Özçakır, 2019; Yozgat vd., 2018), beşinde ilkokul (Çevik, 2016; Demircioğlu \& Kavgacı, 2020; Karasu, 2019; Kaya, 2016; Kocadăg, 2009), birinde ana sınıfı (Demircioğlu \& Kavgacı, 2020) ve yine birinde lise (Karasu, 2019) düzeyinde öğrencilerin katılımcı olarak yer aldığı görülmüştür. Ayrıca çalışmaların ikisinde özel eğitim ve rehabilitasyon merkezinde destek eğitim alan (Demir, 2008; Karasu, 2019) ve birinde özel eğitim uygulama okulunda öğrenim gören (Demircioğlu \& Kavgac1, 2020) öğrenciler katılımcı olarak yer almıştır. 


\section{Şekil 4}

Zihin Yetersizliği Olan Öğrencilere Sinıf Düzeylerine Göre Dağılımları

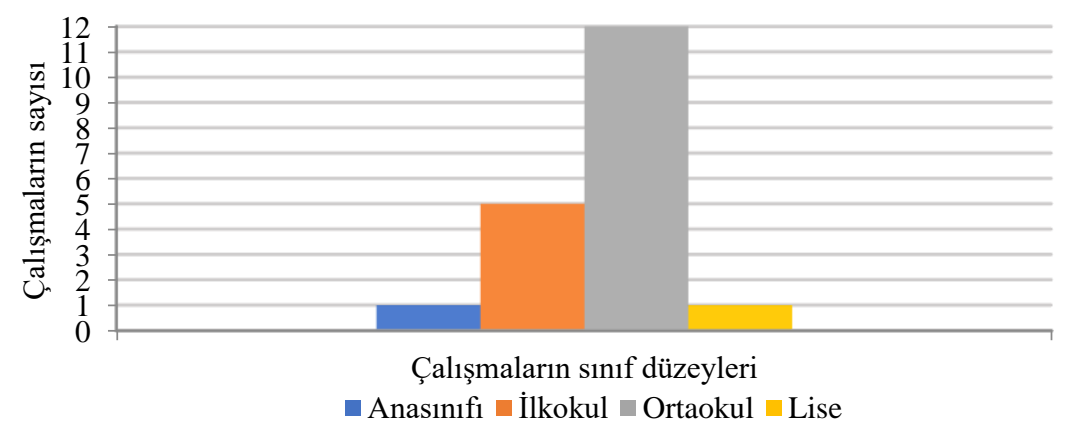

\section{Çalışmalardaki Fen Konu Alanına Göre Dağı̆ımlar}

Zihin yetersizliği olan öğrencilere fen kavram, bilgi, becerilerinin öğretiminde yapılan çalışmaların konu alanlarına göre dağılımları Şekil 5'te yer almaktadır. Araştırmada yer alan çalışmalardaki fen konu alanları incelendiğinde, çalışmaların 10'unda canlılar ve yaşam (Çıkıll-Soylu vd., 2019; Çevik, 2016; Demir, 2008; Karabulut, 2020; Karasu, 2019; Kaya, 2016; Öner, 2018; Tezcan, 2012; Türker \& Çifci-Tekinarslan, 2020; Yıkmış \& Varol-Özçakır, 2019), beşinde madde ve doğası (Çapraz, 2016; Mete \& Yıldırım, 2020; Sola-Özgüç \& Cavkaytar, 2016; Tezcan, 2012; Yozgat vd., 2018), üçünde fiziksel olaylar (Demircioğlu \& Kavgacı, 2020; Tezcan, 2012; Tosun, 2019) ve birinde dünya ve evren (Kocadağ, 2009) konu alanlarına yer verildiği görülmüştür.

\section{Şekil 5}

Zihin Yetersizliği Olan Öğrencilere Fen Kavram, Bilgi, Becerilerin Öğretiminde Yapılan Çalısmaların Konu Alanlarına Göre Dağıllımları

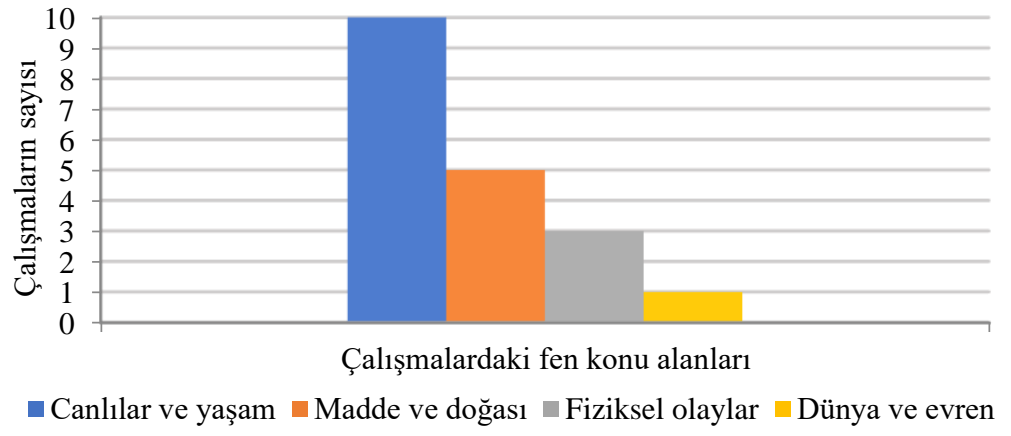

\section{Çalış̧malardaki Müdahalelere Göre Dağılımlar}

Zihin yetersizliği olan öğrencilere fen kavram, bilgi, becerilerini öğretimine yönelik çalışmalardaki müdahalelere göre dağılımlar Şekil 6'da yer almaktadır. Çalı̧̧malardaki müdahaleler incelendiğinde, altı çalışmada doğrudan öğretim yöntemi (Çapraz, 2016; Çıkı11-Soylu vd., 2019; Karabulut, 2020; Mete \& Yıldırım, 2020; Türker \& Çifci-Tekinarslan, 2020; Yozgat vd., 2018), dört çalı̧̧mada teknoloji destekli öğretim (Kocadağ, 2009; Öner, 2018; Sola-Özgüç \& Cavkaytar, 2016; Tezcan, 2012), iki çalışmada doğrudan öğretim yöntemiyle sunulan alternatif değerlendirme teknikleri (Türker \& Çifci-Tekinarslan, 2020; Yıkmış \& Varol-Özçakır, 2019), bir çalışmada proje tabanlı öğretim (Çevik, 2016), bir çalışmada basamaklandırılmış öğretim yöntemi (Demir, 2008), bir çalışmada görsel ve işitsel ipucu (Demircioğlu \& Kavgac1, 2020), bir çalışmada 5E yöntemi (Karasu, 2019), bir çalışmada sabit bekleme süreli öğretim yöntemi (Kaya, 2016), bir çalışmada şematik düzenleyici (ÇıkılıSoylu vd., 2019), bir çalışmada doğrudan öğretim yöntemiyle sunulan teknoloji destekli öğretim (Karabulut, 2020) ve yine bir çalışmada da STEM eğitimi (Tosun, 2019) müdahaleleri yer almaktadır. 


\section{Şekil 6}

Zihin Yetersizliği Olan Öğrencilere Fen Kavram, Bilgi, Becerilerin Öğretimine Yönelik Çalı̧malardaki Müdahalelere Göre Dağıllimlar

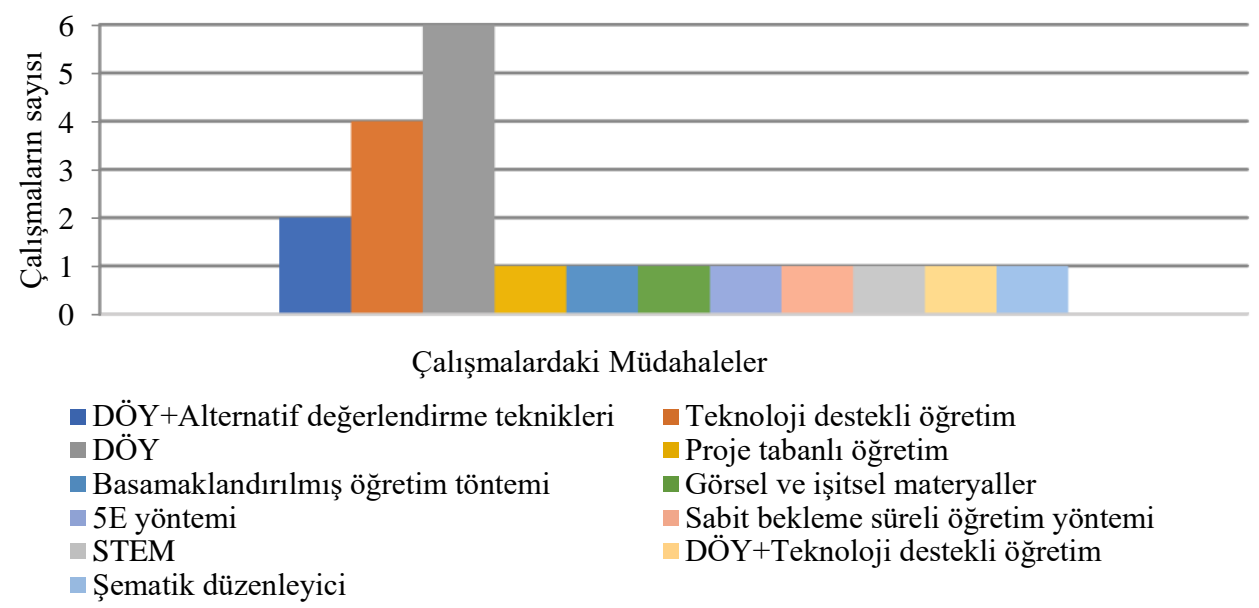

Not: DÖY = Doğrudan öğretim yöntemi, STEM = Fen teknoloji mühendislik matematik.

\section{Çalışmalardaki Müdahale Süresine Göre Dağılımlar}

Zihin yetersizliği olan öğrencilere fen kavram, bilgi, becerilerinin öğretimine yönelik çalışmalardaki müdahale süresi incelendiğinde, en uzun müdahale süresinden en kısa müdahale süresine göre 18 hafta (Tosun, 2019), 14 hafta (Tezcan, 2012), 12 hafta (Sola-Özgüç \& Cavkaytar, 2016; Yıkmış \& Varol-Özçakır, 2019), 11 hafta (Çapraz, 2016), beș hafta (Mete ve Yıldırım, 2020), dört hafta (Kaya, 2016; Demir, 2008), iki hafta (Türker \& Çifci-Tekinarslan, 2020), bir hafta (Karabulut, 2020), üç gün (Çıkıll-Soylu vd., 2019), iki gün (Karasu, 2019) olarak müdahalelerin gerçekleştirildiği görülmüştür. Beş çalışmada ise (Çevik, 2016; Demircioğlu \& Kavgacı, 2020; Kocadağ, 2009; Öner, 2018; Yozgat vd., 2018) hafta veya gün olarak müdahale süresi belirtilmemiştir.

Müdahalelerde gerçekleştirilen oturum sayısı ve her bir oturumun süresi incelendiğinde ise en fazla oturum sayısından en az oturum sayısına göre 96 oturum, her bir oturum $40 \mathrm{dk}$. (Çapraz, 2016), 65 oturum, her bir oturum $90 \mathrm{dk}$. (Karabulut, 2020), 50 oturum, her bir oturum $20 \mathrm{dk}$. (Demir, 2008), 48 oturum, her bir oturum 40 dk. (Sola-Özgüç \& Cavkaytar, 2016), 18 oturum, her bir oturum 40 dk. (Öner, 2018), 12 oturum, her bir oturum 28 dk. (Yıkmış \& Varol-Özçakır, 2019), 12 oturum, her bir oturum 25 dk. (Çıkılı-Soylu vd., 2019), 10 oturum, her bir oturum $28 \mathrm{dk}$. (Türker \& Çifci-Tekinarslan, 2020), iki oturum, her bir oturum $80 \mathrm{dk}$. (Karasu, 2019) olacak şeklinde müdahalelerin gerçekleştirildiği görülmüştür.

Dört çalışmada ise (Çevik, 2016; Demircioğlu \& Kavgac1, 2020; Kocadağ, 2009; Tezcan, 2012) müdahalelerin oturum sayısı ve her bir oturumun süresi belirtilmemiştir. Yine dört çalışmada müdahalelerin oturum sayısı belirtilmesine karşın her bir oturumun süresi belirtilmemiştir. Bu çalışmalarda gerçekleştirilen müdahalelerin oturum sayısı ise sırasıyla 91 oturum (Mete \& Yıldırım, 2020), 36 oturum (Tosun, 2019), 15 oturum (Yozgat vd., 2018) ve 11 oturum (Kaya, 2016) olarak belirtilmiştir.

\section{Çalışmalardaki Veri Toplama Araçlarına Göre Dağılımlar}

Zihin yetersizliği olan öğrencilere fen kavram, bilgi, becerilerinin öğretimine yönelik çalışmalardaki veri toplama araçlarına göre dağılımlar Şekil 7'de yer almaktadır. Araşıırmada yer alan çalışmalardaki veri toplama araçları incelendiğinde, çalışmaların dokuzunda ölçüt bağımlı ölçü aracı (Çıkıl1-Soylu vd., 2019; Demir, 2008; Karabulut, 2020; Kocadağ, 2009; Sola-Özgüç \& Cavkaytar, 2016; Tosun, 2019; Türker \& Çifci-Tekinarslan, 2020; Yıkmış \& Varol-Özçakır, 2019; Yozgat vd., 2018), sekizinde fen konu, kavram, bilgi ve becerilerin öğretilmesi için gerçekleştirilen müdahaleler sonucunda öğrencilerde gözlemlenen doğru tepki, yanlış tepki ve tepkisiz davranışların kaydedilmesini sağlayan davranış kontrol listesi (Çapraz, 2016; Demircioğlu \& Kavgacı, 2020; Karasu, 2019; Kaya, 2016; Mete \& Yıldırım, 2020; Sola-Özgüç \& Cavkaytar, 2016; Tosun, 2019; Yıkmış \& VarolÖzçakır, 2019), beşinde başarı testi (Çevik, 2016; Öner, 2018; Tezcan, 2012; Tosun, 2019; Türker \& ÇifciTekinarslan, 2020) kullanılmıştır. Ayrıca çalışmaların birinde gözlem formu (Sola-Özgüç \& Cavkaytar, 2016), 
birinde görüşme formu (Çevik, 2016), birinde tutum ölçeği (Çevik, 2016), birinde belge incelemesi (Sola-Özgüç \& Cavkaytar, 2016), birinde araştırmacı günlüğü (Sola-Özgüç \& Cavkaytar, 2016), birinde toplantı tutanakları (Sola-Özgüç \& Cavkaytar, 2016), birinde tanılayıcı dallanmış ağaç (Türker \& Çifci-Tekinarslan, 2020), birinde çalışma kağıtları (Yozgat vd., 2018) ve yine birinde de kavram haritası (Yıkmış \& Varol-Özçakır, 2019) veri toplama araçlarının kullanıldığı görülmüsştür.

\section{Şekil 7}

Zihin Yetersizliği Olan Öğrencilere Fen Kavram, Bilgi, Becerilerin Öğretimine Yönelik Çalışmalardaki Veri Toplama Araçlarına Göre Dă̆llımlar

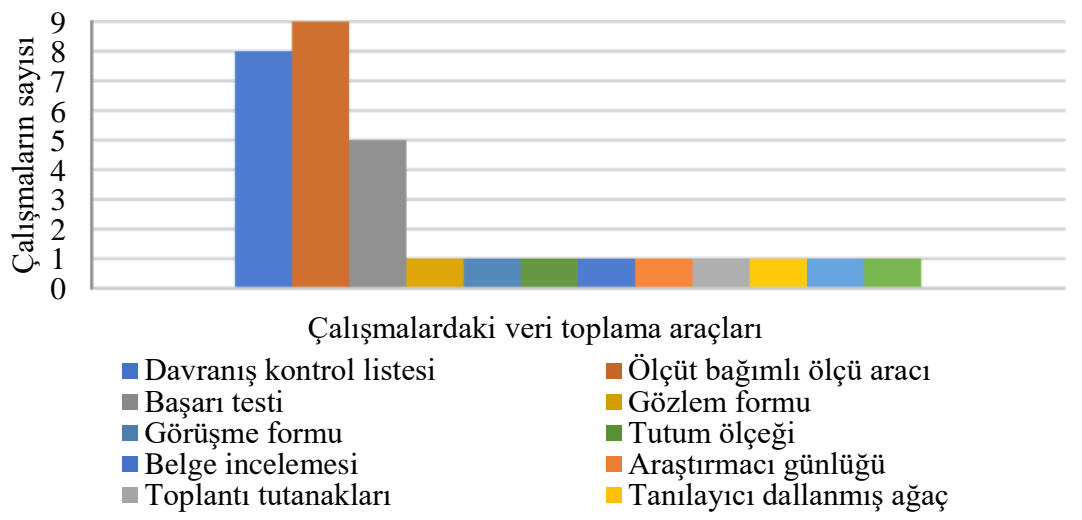

\section{Çalışmalardaki Geçerlik ve Güvenirlik Verilerinin Dağılımı}

Zihin yetersizliği olan öğrencilere fen kavram, bilgi, becerilerinin öğretimine yönelik çalışmalardaki, geçerlik ve güvenirlik verileri Şekil 8'de yer almaktadır. Araştırmada yer alan çalışmalardaki geçerlik ve güvenirlik verileri incelendiğinde, çalışmaların yedisinde uygulama güvenirliği (Çıkıll-Soylu vd., 2019; Karabulut, 2020; Kaya, 2016; Tosun, 2019; Türker \& Çifci-Tekinarslan, 2020; Yıkmış \& Varol-Özçakır, 2019; Yozgat vd., 2018), altısında gözlemciler arası güvenirlik (Çıkı11-Soylu vd., 2019; Karabulut, 2020; Tosun, 2019; Türker \& Çifci-Tekinarslan, 2020; Yıkmış \& Varol-Özçakır, 2019; Yozgat vd., 2018), üçünde sosyal geçerlik (Karabulut, 2020; Türker \& Çifci-Tekinarslan, 2020; Yıkmış \& Varol-Ö̈zçakır, 2019), ikisinde cronbach alfa (Çevik, 2016; Kocadağ, 2009), ikisinde veri çeşitlemesi (Mete ve Y1ldırım, 2020; Sola-Özgüç \& Cavkaytar, 2016), ikisinde kodlama güvenirliği (Çevik, 2016; Sola-Özgüç \& Cavkaytar, 2016) ve yine ikisinde de uzman incelemesi (Mete \& Yıldırım, 2020; Sola-Özgüç \& Cavkaytar, 2016) kullanılmıştır. Ayrıca çalışmaların birinde madde güçlüğü (Çevik, 2016), birinde madde ayırt ediciliği (Çevik, 2016), birinde yapı geçerliği (Çevik, 2016), birinde kapsam geçerliği (Çevik, 2016) ve birinde puanlayıcılar arası tutarlılık incelemesi (Mete \& Yıldırım, 2020) ve yine birinde de teyit incelemesi (Mete \& Yıldırım, 2020) kullanılmıştır. Bunların yanı sıra çalışmaların beşinde ise (Çapraz, 2016; Demir, 2008; Demircioğlu \& Kavgacı, 2020; Karasu, 2019; Öner, 2018) geçerlik ve güvenirlik verisine ilişkin herhangi bir bilgi verilmediği görülmüştür. 


\section{Şekil 8}

Zihin Yetersizliği Olan Öğrencilere Fen Kavram, Bilgi, Becerilerin Öğretimine Yönelik Çalışmalardaki Geçerlik ve Güvenirlik Verilerine Göre Dağllımlar

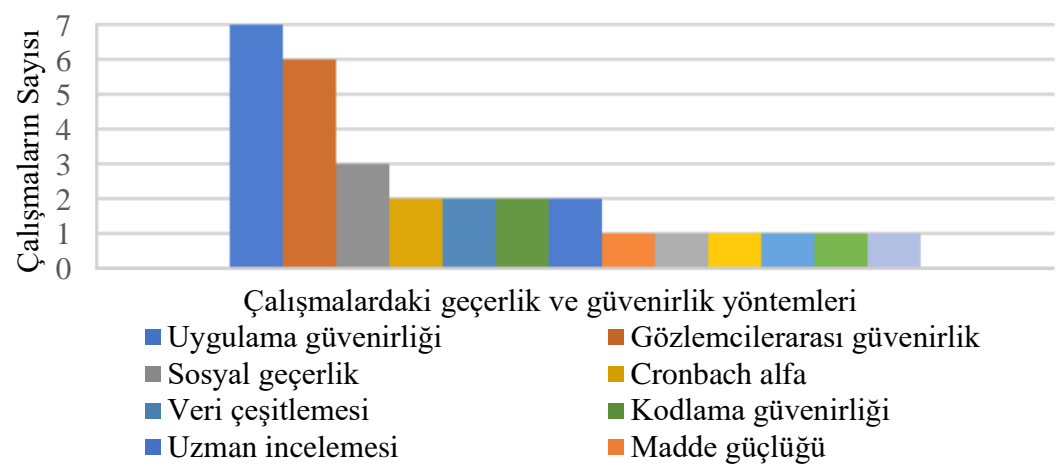

\section{Çalışmaların Bulgularına Göre Dağılımları}

Çalışmaların bulguları incelendiğinde, müdahalenin etkililiğinin incelendiği dokuz çalışmada çok büyük oranda etkili sonuçların elde edildiği görülmüş olup (Çapraz, 2016; Demir, 2008; Demircioğlu \& Kavgacı, 2020; Karasu, 2019; Kaya, 2016; Öner, 2018; Tezcan, 2012; Yıkmış \& Varol-Özçakır, 2019; Yozgat, 2018), yalnızca bir çalışmada yer alan üç katılımcıdan biri üzerinde etkililiği incelenen müdahalenin etkili olmadığı görülmüştür (Mete \& Yıldırım, 2020). Müdahalenin etkililiğinin karşılaştırıldığı üç çalışmada da (Çıkılı-Soylu vd., 2019; Karabulut, 2020; Türker \& Çifci-Tekinarslan, 2020), karşılaştırılan müdahalelerin her ikisinin de etkili olduğu ancak bir çalışmada (Türker \& Çifci-Tekinarslan, 2020) karşılaştırılan doğrudan öğretim yöntemiyle birlikte tanılayıcı dallanmış ağaç tekniğginin yer aldığı öğretim planı ile sadece doğrudan öğretim yönteminin yer aldığı öğretim planı müdahaleleri arasında doğrudan öğretim yöntemiyle birlikte tanılayıcı dallanmış ağaç tekniğinin yer aldığı öğretim planı lehine verimlilik açısından bir farklılık olduğu elde edilmiştir. Müdahale ile yeterlik, başarı, ilgi ve tutum üzerindeki değişimin incelendiği çalışmaların bulgularında ise (Çevik, 2016; Kocadağ, 2009; SolaÖzgüç \& Cavkaytar, 2016; Tosun, 2019) müdahalelerin öğrencilerin fen bilimleri dersine yönelik yeterlik ve başarısını artırdığı, ilgi ve tutumları üzerinde olumlu yönde değişim sağladığı ortaya çıkarılmıştır.

\section{Tartışma}

Bu araştırmada 2008-2020 yılları arasında zihin yetersizliği olan ögrencilere fen kavram, bilgi ve becerilerinin öğretilmesi için kullanılan müdahalelerin yer aldığı Türkiye'de gerçekleștirilmiş olan 17 çalışma incelenmiştir. İncelenen çalışmalar çalışmanın amacı, çalışmanın yöntemi, katılımcılar ve özellikleri (sınıf düzeyi, sayı, cinsiyet, tanı), fen konu alanı, müdahale, müdahale süresi, veri toplama aracı, geçerlik ve güvenirlik verileri ile bulgular olarak kategorilere ayrılmış ve analiz edilmiştir. Araştırmada yer alan çalışmaların yıllara göre dağılımları incelendiğinde, zihin yetersizliği olan öğrencilere fen konu, kavram, bilgi ve becerilerin öğretilmesi için kullanılan müdahalelerin yer aldığı Türkiye'de yapılan ilk çalışmanın 2008 y1lında olduğu görülmüştür. 2008 yılını sırasıyla bir çalışma ile 2009, bir çalışma ile 2012, dört çalışma ile 2016, iki çalışma ile 2018, dört çalışma ile 2019 ve dört çalışma ile 2020 yılı takip etmiştir. Gerçekleştirilen ilk çalışmanın 2008 yılında olduğu, çalışma alanının 2000'li yıllarda araştırmacılar tarafından incelenmeye başladığı ve en çok çalışmanın 2016, 2019 ve 2020 yıllarında gerçekleştirildiği görülmüştür. Gözlenen bu artış araştırmacıların, zihin yetersizliği olan öğrencilere fen konu, kavram, bilgi ve becerilerin öğretilmesi çalı̧̧ma alanına yöneldiğini göstermektedir. Ancak zihin yetersizliği olan öğrencilerin gelişim ve öğrenme özelliklerine uygun ve fen öğretimine yönelik farklı uygulamaların otaya çıkarılmasında, fen öğretimine yönelik müdahalelerin gerçekleștirildiği çalıșmaların oldukça önemli olduğu ve daha fazla çalışmaya ihtiyacın olduğu düşünülmektedir. Bu durum Mete ve diğerleri (2017) tarafindan gerçekleştirilen bir araştırmada da vurgulanmakta, alanyazında gerçekleştirilen çalışmaların Fen Bilimleri Dersi Öğretim Programında (2018) hedeflenen, tüm öğrencilerle birlikte zihin yetersizliği olan öğrencilere bilgi ve beceri kazandırılması ile etkili bir öğrenme-öğretme sürecinin oluşturulmasına katkıda bulunacağı düşünülmektedir. 

INCELENMESI

İncelenen çalışmalarda bir müdahalenin etkililiği, birden fazla müdahalenin karşılaştırılması ve müdahalenin öğrenci yeterlik, başarı, ilgi ve tutumu üzerine etkisinin incelenmesinin amaçlandığı ortaya çıkarılmıştır. Bu amaçlar arasında 10 çalışma ile bir müdahalenin etkililiğinin incelendiği çalışmaların ön planda olduğu görülmüştür. İncelenen çalışmalar arasında, müdahalelerin etkililiğinin incelendiği çalışmaların büyük oranda fazla olmasının, zihin yetersizliği olan öğrencilere fen öğretimine yönelik, etkili müdahalelerin ortaya çıkarılması açısından önemli olduğu düşünülmekte ve elde edilen bu bulgunun alanyazında gerçekleştirilmiş olan çeşitli araştırma bulgularıyla da (Knight vd., 2020; Wright vd., 2020) tutarlık gösterdiği görülmüştür. Fen Bilimleri Dersi Öğretim Programı (2018), etkili bir öğrenme-öğretme sürecini, dolayısıyla tüm öğrencilerin fen bilimleri dersine yönelik temel bilgi becerileri öğrenebilmesi ve günlük yaşamda uygulayabilmesini hedeflemektedir. Etkili bir öğrenme-öğretme süreci ise geliştirilen etkili müdahalelerle mümkün olmakta (Knight vd., 2013; Mastropieri vd., 1999; Mastropieri vd., 2001), dolayısıyla araştırmadan elde edilen bu bulgunun etkili müdahalelerin ortaya çıkarılması açısından oldukça önemli olduğu düşünülmektedir.

Çalışmaların yöntemi incelendiğinde, sekiz çalışma ile en çok kullanılan yöntemin tek denekli araştırma ve altı çalışma ile nitel araştırma yöntemleri olduğu ortaya çıkarılmıştır. Kullanılan bu yöntemlerin oldukça fazla olmasının, zihin yetersizliği olan öğrencilerin bireysel farklılıklarından kaynaklandığı ve bu nedenle katılımcı sayısında meydana gelen sınırlılık olduğu düşünülmektedir. Ayrıca bireysel farklılıklardan dolayı, her bireyin kendi içinde değerlendirilmesine firsat vermesi nedeniyle tek denekli araştırma yöntemlerinin (Tekin-İftar, 2012) oldukça sık kullanıldığı düşünülmektedir.

Çalışmalardaki katılımcıların cinsiyet ve sınıf düzeylerine ilişkin özellikleri incelendiğinde, 17 çalışmada toplam 131 katılımcının yer aldığı bu katılımcıların 58'inin erkek 31'inin ise kadın olduğu görülmüştür. Çalışmalarda yer verilen sınıf düzeylerine yönelik ise 12 çalışma ile en çok yer verilen sınıf düzeyinin ortaokul olduğu ortaya çıkarılmıştır. Bu sınıf düzeyini beş çalışma ile ilkokul, bir çalışma ile anasınıfı ve bir çalışma ile lise düzeyinin takip ettiği görülmüştür. Çalışmalarda ortaokul ve bunun ardından ilkokul sınıf düzeyinin en çok karşılaşılan sınıf düzeyi olarak karşımıza çıkmasına sebep olarak fen bilimleri dersinin ilkokul ve ortaokul sınıf düzeylerinde öğrencilerin karşısına çıkan bir ders olmasından kaynaklandığı düşünülmektedir. İlkokul ve ortaokul sınıf düzeylerinde fen kavram, bilgi ve becerileri öğrencilere kazandırıldığı için bu sınıf düzeylerinin çalışmalarda yoğun olarak kullanıldığı düşünülmektedir.

İncelenen çalışmalardaki fen konu alanları incelendiğinde, 10 çalışma ile canlılar ve yaşam konu alanının en çok yer verilen konu alanı olduğu ortaya çıkarılmıştır. Bu konu alanını beş çalışma ile madde ve doğası, üç çalışma ile fiziksel olaylar konu alanları takip etmiştir. Canlılar ve yaşam konu alanının, öğretimde daha sık kullanılmasına neden olarak, bu konunun zihin yetersizliği olan öğrencilerin günlük yaşamda karşısına çıkabilecek kavram, bilgi ve becerileri içermesinden kaynaklandığı düşünülmektedir. Zihin yetersizliği olan öğrencilerin, içinde bulunduğu çevrede yer alan kavram, bilgi ve becerileri kazandığı sürece fen bilimleri dersini öğrenmelerinin daha anlamlı olacağı dolayısıyla araştırmadan elde edilen bu bulgunun oldukça önemli olduğu düşünülmektedir.

İncelenen çalışmalarda yer alan müdahalelere yönelik elde edilen bulgular incelendiğinde, altı çalışma ile doğrudan öğretim yöntemi ve dört çalışma ile teknoloji destekli öğretim yöntemlerinin en çok yer verilen müdahaleler olduğu görülmüştür. Araştırmalarda yer alan müdahalelere yönelik doğrudan öğretim yönteminin daha çok karşımıza çıkması, doğrudan öğretim yönteminin öğretim sürecinde sorumluluğun öğretmenden öğrenciye basamak basamak aktarılmasına ve öğretimde bol örneğe yer verilerek birden fazla öğretim materyali kullanılmasına fırsat vermesi ayrıca fen bilimleri dersindeki özel gereksinimli öğrencilerin başarısını artırması açısından (Türker \& Çifci-Tekinarslan, 2020) oldukça önemli görülmektedir. Çalışmalarda oldukça sık verilen müdahale olarak karşımıza çıkan teknoloji destekli öğretim yöntemine yönelik elde edilen bulgu ise özel gereksinimli öğrencilerin fen bilimleri dersindeki motivasyon ve ilgisinin arttırılması ve teknolojinin sağladığı görsel ve işitsel imkanlar ile öğrencilerde düşünme ve öğrenme becerisinin geliştirilmesi açısından (Sola-Özgüç \& Cavkaytar, 2016) önemli görülmektedir. Ayrıca incelenen çalışmalarda, özel gereksinimli öğrencilerin akademik başarı ve motivasyonunu artıran, fen bilimleri dersine yönelik tutumların olumlu yönde gelişmesini sağlayan ve öğrenci merkezli müdahalelerin yer almasının oldukça önemli olduğu ve elde edilen bu bulgunun alanyazında Karaer ve Melekoğlu (2020) tarafından gerçekleştirilen araştırmanın bulgusuyla da tutarlılık gösterdiği görülmektedir.

Çalışmalarda yer verilen müdahale süresine yönelik elde edilen bulgular incelendiğinde, müdahale sürelerinin birbirinden farklılık gösterdiği görülmekte bu nedenle kesin bir değerlendirme yapılamamaktadır. Çalışmalardaki fen konu içeriği ve müdahaleler birbirinden farklılık gösterdiği için müdahale süresine yönelik elde edilen verilerin de birbirinden farklılık gösterdiği düşünülmektedir. 
Çalışmalarda yer alan veri toplama araçlarına yönelik, dokuz çalışma ile ölçüt bağımlı ölçü aracı ve sekiz çalışma ile davranış kontrol listesinin çalışmalarda en çok yer verilen veri toplama araçları olduğu bulgusu elde edilmiştir. Öğretmen tarafından hazırlanan bir informal ölçü aracı olan davranış kontrol listeleri ve ölçüt bağımlı ölçme araçları, öğrencilerin işlevde bulunma düzeyini belirleyerek öğrenciye yönelik öğretim planının hazırlanması ve hedeflenen amaca göre öğrenmenin hangi düzeyde gerçekleştirildiğinin tespit edilmesini sağlamaktadır (Kargın, 2007). Öğrencinin performansı ve gereksinimlerinin açıkça belirlenmesi ve bireysel olarak hazırlanan öğretim planına göre öğrencinin ilerleme düzeyi ve belirlenen amaçlarını gerçekleştirilip gerçekleştirilmediğinin ortaya çıkarılmasını sağlayan ölçüt bağımlı ölçü araçlarına yönelik (Topbaş, 1998) elde edilen bu bulgunun oldukça önemli olduğu düşünülmektedir.

Çalışmaların sonuçlarından elde edilen bulgular incelendiğinde, çalışmaların büyük çoğunluğunda öğrencilerin fen kavram, bilgi ve becerileri kazandığı, öğrencilerin fen bilimleri dersine yönelik yeterlik ve başarısının arttığı (Çapraz, 2016; Çıkılı-Soylu vd., 2019; Demir, 2008; Demircioğlu \& Kavgacı, 2020; Karabulut, 2020; Karasu, 2019; Kaya, 2016; Öner, 2018; Tezcan, 2012; Türker \& Çifci-Tekinarslan, 2020; Y1kmış \& VarolÖzçakır, 2019; Yozgat vd., 2018), gerçekleştirilen çalışmaların ilgi ve tutumlar üzerinde olumlu yönde değișim sağladığı (Çevik, 2016; Kocadağ, 2009; Sola-Özgüç \& Cavkaytar, 2016; Tosun, 2019) ortaya çıkmıştır. Elde edilen bu bulguların, öğrenme hızları tipik gelişim gösteren akranlarından daha yavaş olan özel gereksinimli öğrencilerin öğrenme yaşantılarının akranlarıyla benzer özellik gösterdiği ve özel gereksinimli öğrencilerin de fen bilimleri dersi kavram, bilgi ve becerilerini kazanabildiğinin ortaya çıkarılması açısından oldukça önemli olduğu düşünülmektedir. Ayrıca bir çalışmada uygulanan müdahale sonucunda, üç katılımcının birinde öğrenmenin gerçekleşmediği bulgusuna yönelik, öğrenciye daha fazla zaman ayrılması ve uygulama sürecinde farklı materyallere yer verilmesinin gerekli olduğu ilgili çalışmada da belirtilmiştir (Mete \& Yıldırım, 2020).

Sonuç olarak Türkiye'deki alanyazında, zihin yetersizliği olan öğrencilere fen kavram, bilgi ve becerilerin öğretilmesinde; müdahalelerin etkililiği, etkililiğinin karşılaştırılması ve yeterlik, başarı, ilgi ve tutum üzerindeki etkisinin incelendiği çalışmaların gerçekleştirildiği görülmüştür. Bu araştırma da zihin yetersizliği olan öğrencilere fen kavram, bilgi ve becerilerinin öğretilmesi için kullanılan müdahalelerin yer aldığı Türkiye'de gerçekleştirilmiş olan çalışmaları incelediği ve konuyla ilgili etkili müdahaleleri ortaya koyduğu için önemli görülmektedir. Elde edilen sonuçların, fen bilimleri dersine yönelik fen kavram, bilgi ve becerilerin, zihin yetersizliği olan öğrencilere kazandırılması konusunda çalışacak araştırmacılara yararlı olacağı ve 1şık tutacağı düşünülmektedir. Bunun yanı sıra bu çalışmanın, zihin yetersizliği olan öğrencilerle çalışan öğretmenlerin bilgi dağarcığını geliştireceği ve öğrencilere fen kavram, bilgi ve becerilerin kazandırılması için gerçekleştirilen uygulamalar konusunda bilgi vereceği düşünülmektedir. İleri araştırmalara yönelik olarak, farklı yetersizliğe sahip öğrencilere fen kavram, bilgi ve becerilerin kazandırıldığı çalışmaların incelenmesi önerilmektedir. Ayrıca ileri araştırmalarda, bu araştırmada yer alan her bir müdahale ya da farklı müdahaleler ile özel gereksinimli öğrencilere fen konu, kavram, bilgi, becerilerin kazandırılması önerilmektedir. 


\section{Kaynaklar}

Akay, E. (2011). Kaynaştırma ortamındaki işitme engelli ilköğretim ögrencilerine sunulan destek ĕgitim odası sürecinin incelenmesi [An examination of the process of the resource room application designed for the mainstreamed primary school aged hearing impaired students] (Tez Numarası: 298173) [Yüksek lisans tezi, Anadolu Üniversitesi]. Yükseköğretim Kurulu Ulusal Tez Merkezi.

Akdağ, E. M., Köksal, M. S., \& Ertekin, P. (2017). Üstün yetenekli ortaokul öğrencilerinin fen öğrenmede zihinsel risk alma davranışlarının sınıf düzeyi ve cinsiyet değişkenleri açısından incelenmesi [Investigating gifted middle school students' intellectual risk taking behaviors in learning science across gender and grade]. Adnan Menderes Üniversitesi Sosyal Bilimler Enstitüsü Dergisi, 4(2), 16-25. https://doi.org/10.30803/adusobed.321024

Aktürel, İ. E. (2004). İşitme engelli öğrencilerin fen öğretimine verdikleri yanıt ve öğrenci özellikleri bakımından incelenmesi [Examine the physics lesson in the integration applications at the level of the vocational high school] (Tez Numaras1: 143839) [Yüksek lisans tezi, Anadolu Üniversitesi]. Yükseköğretim Kurulu Ulusal Tez Merkezi.

Alptekin, S. (2010). Akranların sosyal becerilere model olduğu doğrudan öğretimin zihinsel engelli öğrencinin sosyal becerileri kazanmast, sürdürmesi, genellemesi ve sosyal kabulüne etkisi [The effect of direct instruction with modeling the social skills by the peers of the mentally retarded student on his/her acquiring, maintaining and generalizing the social skills and his/her social acceptance] (Tez Numaras1: 279691) [Doktora tezi, Gazi Üniversitesi]. Yükseköğretim Kurulu Ulusal Tez Merkezi.

Aracı, N. (2019). Bellek destekleyici stratejilerden anahtar sözcük stratejisinin özel öğrenme güçlügü olan ögrencilerin ilkokul fen kavramlarını ögrenmelerine etkisi [The impact of a mnemonic strategy, the keyword strategy, on learning elementary science concepts of students with specific learning disabilities] (Tez Numarası: 573476) [Yüksek lisans tezi, Bolu Abant İzzet Baysal Üniversitesi]. Yükseköğretim Kurulu Ulusal Tez Merkezi.

Aslan, K., Karamustafaoğlu, O., \& Kurt, M. (2018). Otizmli öğrencilere bir eğitsel oyunla "iç organlarını tanıyabilme" konusunun öğretimi. [Teaching of 'knowing internal organs' subject through educational game to the students with autism]. Abant İzzet Baysal Üniversitesi Ë̈itim Fakültesi, 18(4), 1887-1902. https://doi.org/10.17240/aibuefd.2018.18.41844-456957

Ayverdi, L. (2018). Özel yetenekli öğrencilerin fen eğitiminde teknoloji, mühendislik ve matematiğin kullanımı: FETEMM yaklaşımı [Usage of technology, engineering and mathematics in science education for gifted students: STEM approach] (Tez Numaras1: 529581) [Doktora tezi, Balıkesir Üniversitesi]. Yükseköğretim Kurulu Ulusal Tez Merkezi.

Balım, S. (2016). Fen bilimleri dersinde probleme dayalı ögrenme yöntemi kullanımının üstün yetenekli ögrencilerin akademik başarları, sorgulayıcı ögrenme beceri algıları ve fene yönelik tutumları üzerindeki etkileri [The effects of using problem based learning method in science courses on talented students' levels of academic achievements, inquiry learning skill perceptions and attitudes towards science] (Tez Numarası: 430717) [Yüksek lisans tezi, Dokuz Eylül Üniversitesi]. Yükseköğretim Kurulu Ulusal Tez Merkezi.

Barış, N., \& Ecevit, T. (2019). Özel yetenekli öğrencilerin eğitiminde STEM uygulamaları [STEM education for gifted student]. Necatibey Ĕ̆itim Fakültesi Elektronik Fen ve Matematik Eğitimi Dergisi, 13(1), 217-233. https://doi.org/10.17522/balikesirnef.529898

Biçer, A. (2019). STEM yaklaşımına dayalı elektrik devre elemanları konusu öğretiminin 5. sınıf özel ögrenme güçlüğ̈̈ olan ögrencilerin akademik başarılarına ve kalıcılı̆̆ına etkisi [The effect of stem approach based electrical circuit elements teaching on the academic achievement of 5th-grade students with specific learning disabilities] (Tez Numarası:535611) [Yüksek lisans tezi, Aksaray Üniversitesi]. Yükseköğretim Kurulu Ulusal Tez Merkezi. 

INCELENMESI

Bilgiç, H. C., \& Şafak, P. (2020). Çoklu yetersizliği olan öğrencilere doğrudan öğretimle sunulan şematik düzenleyicinin bir fen konusunun öğretimine etkisi [The effect of schematic organizer presented with direct teaching to students with multiple disabilities on teaching a science subject]. Ankara Üniversitesi Eğitim Bilimleri Fakültesi Özel Eğitim Dergisi, 22(1), 175-206. https://dergipark.org.tr/en/download/article-file/824237

Courtade, G. R., Browder, D. M., Spooner, F., \& DiBiase, W. (2010). Training teachers to use an inquiry-based task analysis to teach science to students with moderate and severe disabilities. Education and Training in Autism and Developmental Disabilities, 45(3), 378-399. https://www.jstor.org/stable/23880112

Çapraz, C. (2016). Ortaokul özel alt sinıflarda öğrenim gören zihinsel yetersizliği olan öğrencilere doğrudan ögretim yöntemiyle bazı maddelerin "katt-slvl-gaz" hallerinin ögretimi [Teaching solid-liquid-gas states of some substances to students with intellectual disabilities in a secondary special sub-class through direct instruction method] (Tez Numarası: 433815) [Doktora tezi, Atatürk Üniversitesi]. Yükseköğretim Kurulu Ulusal Tez Merkezi.

Çevik, M. (2016). Fen bilimleri dersinde proje tabanlı öğrenme yaklaşımının ilkokulda öğrenim görmekte olan hafif düzeyde zihinsel engele sahip öğrencilerin akademik başarılarına ve tutumlarına etkisi [Effects of the project-based learning approaches on academic achievement and attitude of students studying at primary school with mild mental retardation in sciences course]. Education and Science (NWSAES), 11(1), 36-48. https://dergipark.org.tr/tr/pub/nwsaedu/issue/19843/212570

Çıkılı-Soylu, D., Dağseven-Emecen, D., \& Yıkmış, A. (2019). Zihinsel yetersizliği olan öğrencilere fen konularının öğretiminde doğrudan öğretim yöntemi ile şematik düzenleyiciyle öğretim yönteminin karşılaştırılması [Comparison of direct teaching method and graphic organizers method on teaching science to children with intellectual disability]. Kalem Eğitim ve İnsan Bilimleri Dergisi, 9(1), 1-25. http://dx.doi.org/10.23863/kalem.2019.118

Demir, R. (2008). Zihinsel engelli öğrencilere fen bilgisi dersinde sindirim konusunu basamaklandırılmış öğretim yöntemiyle sunulmasının etkililiği [The effectiveness of teaching digestion curriculum unit through graded teaching method in science classes to mentally-handicapped children] (Tez Numaras1: 178389) [Yüksek lisans tezi, Selçuk Üniversitesi]. Yükseköğretim Kurulu Ulusal Tez Merkezi.

Demircioğlu, G., \& Kavgacı, G. (2020). Zihinsel yetersizliğe sahip öğrencilerin doğal ve yapay sesleri kaynağıyla ilişkilendirme düzeyleri [Levels of students with intellectual disability in associating natural and artificial sounds to their sources]. Sakarya University Journal of Education, 10(1), 29-52. http://dx.doi.org/10.19126/suje.550137

Dönmez, İ., \& İdin, Ş. (2017). Türkiye'de fen bilimleri alanında üstün yetenekli öğrencilerin eğitimi ile ilgili araştırmaların incelenmesi [Science education in Turkey talented in the field about students education review of studies]. Üstün Zekâlılar Eğitimi ve Yaratıcllı Dergisi, 4(2), 57-74. https://dergipark.org.tr/tr/pub/jgedc/issue/38702/449435

Elmaci, E. (2018). Otizm spektrum bozukluğu olan 7. sınıf kaynaştırma öğrencilerine fen bilgisi deneylerinin ögretiminde video-destekli resimli etkinlik çizelgesinin etkililiği [Effects of video enhanced activity schedules on teaching science experiments to the inclusion students with autism enrolled in seventh grade] (Tez Numarası: 530460) [Doktora tezi, Marmara Üniversitesi]. Yükseköğretim Kurulu Ulusal Tez Merkezi.

Eripek, S. (2011). Özel gereksinimli çocuklar ve özel eğitime giriş. A. Ataman (Ed.), Zihinsel yetersizliği olan çocuklar [Children with intellectual disabilities] içinde (ss. 107-122). Gündüz Eğitim ve Yayıncılık.

Hudson, M. E., Browder, D. M., \& Jimenez, B. A. (2014). Effects of a peer-delivered system of least prompts intervention and adapted science read-alouds on listening comprehension for participants with moderate intellectual disability. Education and Training in Autism and Developmental Disabilities, 49(1), 60-77. https://www.jstor.org/stable/23880655 
İlik, Ș. Ş. (2009). Hafif düzeyde ögrrenme güçlüğ̈̈ne sahip öğrencilerde doğrudan öğretim yönteminin fen ve teknoloji dersine ilişkin kavramların ögretiminde etkililiğinin değerlendirilmesi [An evaluation of the effectiveness of direct teaching methods on learning concepts of children with mild learning difficulties related to science and technology course] (Tez Numarası: 235060) [Yüksek lisans tezi, Selçuk Üniversitesi]. Yükseköğretim Kurulu Ulusal Tez Merkezi.

Jimenez, B. A., Browder, D. M., Spooner, F., \& Dibiase, W. (2012). Inclusive inquiry science using peer-mediated embedded instruction for students with moderate intellectual disability. Council for Exceptional Children, 78(3), 301-317. https://doi.org/10.1177/001440291207800303

Kahveci, G. (2004). Az görenlerde zihin haritast yöntemi ile özet çıkarmanın okuduğunu anlamaya etkisi [The effect of summarization by mind mapping strategies on reading comprehension in visually impaired students] (Tez Numarasi: 145170) [Yüksek lisans tezi, Gazi Üniversitesi]. Yükseköğretim Kurulu Ulusal Tez Merkezi.

Kanlı, E. (2008). Fen ve teknoloji ögretiminde probleme dayalı ögrrenmenin üstün ve normal zihin düzeyindeki ögrencilerin erişi, yaratıcı düşünme ve motivasyon düzeylerine etkisi [The effect of problem based learning in science \& technology instruction on gifted and normal students' achievement, creative thinking and motivation levels] (Tez Numarası: 261852) [Yüksek lisans tezi, İstanbul Üniversitesi]. Yükseköğretim Kurulu Ulusal Tez Merkezi.

Kaplan, G., \& Çifci-Tekinarslan, İ. (2013). Zihinsel yetersizliği olan ve olmayan öğrencilerin astronomi kavramlarındaki bilgi düzeylerinin karşılaştırılması [A comparison of knowledge levels of students with and without intellectual disabilities about astronomy concepts]. Illköğretim Online, 12(2), 614-627. https://dergipark.org.tr/tr/pub/ilkonline/issue/8585/106664

Karabulut, H. A. (2020). Zihin yetersizliği olan öğrencilere fen konularının kazandırllmasında doğrudan öğretim yönteminin tabletli ve tabletsiz sunumunun karşılaştırılması [Comparison of direct instruction presented with tablet application and without tablet application in acquisition of science subjects for students with intellectual disabilities] (Tez Numaras1: 611753) [Doktora tezi, Bolu Abant İzzet Baysal Üniversitesi]. Yükseköğretim Kurulu Ulusal Tez Merkezi.

Karaer, G., \& Melekoğlu, M. A. (2020). Özel öğrenme güçlüğü olan öğrencilere fen bilimleri öğretimi üzerine yapılan çalışmaların incelenmesi [Review of studies on teaching science to students with specific learning disabilities]. Ankara Üniversitesi Eğitim Bilimleri Fakültesi Özel Eğitim Dergisi, 21(4), 789-819. https://dergipark.org.tr/en/download/article-file/1028386

Karakoç, T. (2016). Görme yetersizliği olan öğrencilerin araştırmaya dayalı ögrrenme yaklaşımı modellerinden rehberli keşfetme modelinin deneysel işlem becerilerine, akademik başarllarına ve fen bilimleri dersine yönelik tutumlarına etkisi [The contribution of guided discovery model of inquiry-based approach to visually impaired students acquisition of experimental procedures, academic success and attitudes towards sciences] (Tez Numarası: 419357) [Doktora tezi, Selçuk Üniversitesi]. Yükseköğretim Kurulu Ulusal Tez Merkezi.

Karasu, S. (2019). Özel eğitim öğrencilerine fen bilimleri dersinde duyu organları konusunun $5 E$ yöntemi ile sunulmasinin etkililigi [The efficacy of presenting subject of sense organs with method $5 E$ to special education students] (Tez Numarasi: 579787) [Yüksek Lisans tezi, Necmettin Erbakan Üniversitesi]. Yükseköğretim Kurulu Ulusal Tez Merkezi.

Kargın, T. (2007). Eğitsel değerlendirme ve bireyselleştirilmiş eğitim programı hazırlama süreci [The process for educational assessment and individualized education programme]. Ankara Üniversitesi Eğitim Bilimleri Fakültesi Özel Eğitim Dergisi, 8(1), 1-13. https://doi.org/10.1501/Ozlegt_0000000103

Kaya, G. (2016). Hafif düzey zihinsel yetersizliği olan öğrencilere fen bilimleri dersinde "canlı-cansız" kavramının ögretiminde sabit bekleme süreli öğretim yönteminin etkililiğinin incelenmesi [Examining the efficiency of constant time delay procedure in teaching the concept of 'living and non-living' in science class to children with minor mental deficiency] (Tez Numarasi: 448218) [Yüksek lisans tezi, Ege Üniversitesi]. Yükseköğretim Kurulu Ulusal Tez Merkezi. 

INCELENMESI

Kızılaslan, A., \& Sözbilir, M. (2017a). Görme yetersizliği olan öğrencilere yönelik geliştirilen fen etkinliklerin değerlendirilmesi: Isı ve sıcaklık [Assessment of science activities developed for students with visual impairment: Heat and temperature]. Ege Eğitim Dergisi, 18(2), 914-942. https://doi.org/10.12984/egeefd.314586

Kızılaslan, A., \& Sözbilir, M. (2017b). Görme yetersizliği olan öğrencilerin "maddenin halleri ve 1sı" ünitesini öğrenmeye yönelik ihtiyaç analizi [The needs analysis of students with visual impairment related concept of the 'state of matter and heat' units]. Atatürk Üniversitesi Kazım Karabekir Eğitim Fakültesi Dergisi, 35, 274-290. https://dergipark.org.tr/tr/pub/ataunikkefd/issue/33367/331718

Kızılaslan, A., Zorluoğlu, S. L., Sözbilir, M., \& Teke, D. (2020). Görme yetersizliği olan öğrencilere yönelik geliştirilen fen etkinliklerinin analizi: Madde ve 1sı [Analysis of science activities developed for students with visually impaired: Matter and heat]. Anemon Muş Alparslan Üniversitesi Sosyal Bilimler Dergisi, 8(1), 19-32. https://doi.org/10.18506/anemon.524012

Knight, V. F., Smith, B. R., Spooner, F., \& Browder, D. (2012). Using explicit instruction to teach science descriptors to students with autism spectrum disorder. Journal of Autism and Developmental Disorders, 42(3), 378-389. https://doi.org/10.1007/s10803-011-1258-1

Knight, V. F., Spooner, F., Browder, D. M., Smith, B. R., Charles, L., \& Wood, C. L. (2013). Using systematic instruction and graphic organizers to teach science concepts to students with autism spectrum disorders and intellectual disability. Focus on Autism and Other Developmental Disabilities, 28(2), 115-126. https://doi.org/10.1177/1088357612475301

Knight, V. F., Wood, L., McKissick, B. R., \& Kuntz, E. M. (2020). Teaching science content and practices to students with intellectual disability and autism. Remedial and Special Education, 41(6), 327-340. https://doi.org/10.1177/0741932519843998

Kocadağ, T. (2009). Illköğretim 4. slnıf fen ve teknoloji dersinde interaktif eğitim yazılımları kullanımının kaynaştırma ögrencilerinin başarisina etkisi [The effect on the success of the usage of interactive educational software in science and technology lessons for year 4 students in primary school] (Tez Numarasi: 278307) [Yüksek lisans tezi, Gazi Üniversitesi]. Yükseköğretim Kurulu Ulusal Tez Merkezi.

Köse-Biber, S. (2009). Web destekli fen bilgisi öğretiminin kaynaştırma eğitimindeki ilköğretim 7. sinıf ögrencilerinin performans düzeyi ve akademik bașarılarına etkisi [The effect of web supported science education on the academic success and performance level of 7th grade elementary students in mainstreaming education] (Tez Numarası: 255473) [Yüksek lisans tezi, Ege Üniversitesi]. Yükseköğretim Kurulu Ulusal Tez Merkezi.

Mastropieri, M. A., Scruggs, T. E., \& Magnussen, M. (1999). Activities-oriented science instruction for students with disabilities. Learning Disabilities Quartery, 22(4), 240-249. https://doi.org/10.2307/1511258

Mastropieri, M. A., Scruggs, T. E., Boon, R., \& Carter, K. (2001). Correlates of inquiry learning in science: Constructing concepts of density and buoyancy. Remedial and Special Education, 22(3), 130-137. https://doi.org/10.1177/074193250102200301

Mete, P., \& Yıldırım, A. (2018). Zihinsel yetersizliğe sahip öğrencilere "sert-yumuşak" maddelerin öğretimi için öğretim materyallerinin seçim süreci [Selection process of instructional materials for the teaching of "hard-soft" materials to intellectually disabled students]. Kastamonи Education Journal, 26(5), 15271538. https://doi.org/10.24106/kefdergi.2138

Mete, P., \& Yıldırım, A. (2020). Zihinsel yetersizliğe sahip öğrencilere bazı maddelerin "sert-yumuşak" özelliklerinin öğretimi [Teaching of hard and soft features of some materials to students with intellectual disabilities]. Çukurova Üniversitesi Eğitim Fakültesi Dergisi, 49(2), 1255-1290. https://doi.org/10.14812/cufej.665543

Mete, P., Çapraz, C., \& Yıldırım, A. (2017). Zihinsel yetersizliğe sahip öğrenciler için fen eğitimi [Science education for intellectual disabled students]. Atatürk Üniversitesi Sosyal Bilimler Enstitüsü Dergisi, 21(1), 289-304. https://dergipark.org.tr/en/pub/ataunisosbil/issue/35347/425793

Milletlerarası Sözleşme [International Convention]. (2009). T.C. Resmî Gazete, (27288), 14 Temmuz 2009. 

INCELENMESI

Millî Eğitim Bakanlığı [Ministry of National Education]. (2008). Özel eğitim ve rehabilitasyon merkezi zihinsel engelli bireyler destek eğitim programı [Special education and rehabilitation center support training program for mentally handicapped individuals]. https://orgm.meb.gov.tr/meb_iys_dosyalar/2013_09/04010347_zihinselengellibireylerdestekeitimprogra $\underline{\text { m.pdf }}$

Millî Eğitim Bakanlığı [Ministry of National Education]. (2018). Fen bilimleri dersi öğretim programı (ilkokul ve ortaokul 3, 4, 5, 6, 7 ve 8. sinfflar) [Science lesson curriculum (primary and secondary school 3, 4, 5, 6, 7 and 8 th grades)]. https://ttkb.meb.gov.tr/www/ogretim programlari /icerik/72

Millî Eğitim Bakanlığı [Ministry of National Education]. (2017). Öğretmenlik mesleği genel yeterlikleri [General competencies of the teaching profession]. http://oygm.meb.gov.tr/

Nas, S. E., Çoruhlu, T. Ş., Çalık, M., Ergül, C., \& Gülay, A. (2019). Öğrenme güçlüğü yaşayan ortaokul öğrencilerine yönelik fen bilimleri deneyleri kılavuzunun etkililiğinin incelenmesi [Investigating the effectiveness of the science experiments guidebook for students with learning disabilities]. Ankara Üniversitesi Ë̆itim Bilimleri Fakültesi Özel Eğitim Dergisi, 20(3), 501-534. https://doi.org/10.21565/ozelegitimdergisi.484937

Öner, G. (2018). Zihinsel engelli ögrrencilere fen bilimleri dersinde canlıların sinfflandırllmasının bilgisayar destekli bireyselleştirilmiş ögretim yöntemiyle öğretimin etkisi [The effectiveness of teaching classification of living things and plants unit through computer aided teaching method in science courses to mentally-handicapped children] (Tez Numarası: 528809) [Yüksek lisans tezi, Necmettin Erbakan Üniversitesi]. Yükseköğretim Kurulu Ulusal Tez Merkezi.

Özdemir, G. (2017). Üstün yetenekli öğrencilere yönelik zenginleştirilmiş ögretim programının bilimsel süreç becerilerine ve başariya katkisina ilişskin eylem araştırması [An action research about enriched curriculum towards the contribution to scientific process skills and achievement for gifted students] (Tez Numarası: 454914) [Yüksek lisans tezi, Hacettepe Üniversitesi]. Yükseköğretim Kurulu Ulusal Tez Merkezi.

Özkan, Ş. Y., Öncül, N., \& Kaya, Ö. (2013). Effects of computer-based instruction on teaching emergency telephone numbers to students with intellectual disability. Education and Training in Autism and Developmental Disabilities, 48(2), 200-217. https://www.jstor.org/stable/23880640

Peker, E. A., \& Taş, E. (2017). Evde eğitim uygulaması üzerine bir durum çalışması: Evde fen eğitimi [A case study on homeschooling application: Home science education]. Karadeniz Sosyal Bilimler Dergisi, 9(2), 139-174. https://dergipark.org.tr/en/pub/ksbd/issue/34220/383401

Salend, S. J. (1998). Using an activities-based approach to teach science to students with disabilities. Intervention in School and Clinic, 34(2), 67-72. https://doi.org/10.1177/105345129803400201

Sazak-Pınar, E., \& Merdan, F. (2016). Grafik düzenleyicilerin otizmli öğrencilere fen bilgisi kavramlarının öğretimindeki etkililiği [Effectiveness of graphic in teaching science concepts to children with autism]. Ahi Evran Üniversitesi Kurşehir Eğitim Fakültesi Dergisi, 17(1), 111-131. https://dergipark.org.tr/en/pub/kefad/issue/59448/854035

Scruggs, T. E., Mastropieri, M. A., \& Boon, R. (1998). Science education for students with disabilities: A review of recent research. Studies in Science Education, 32(1), 21-44. https://doi.org/10.1080/03057269808560126

Sola-Özgüç, C., \& Cavkaytar, A. (2016). Zihin yetersizliği olan ortaokul öğrencilerinin bulunduğu bir sınıfta öğretim etkinliklerinin teknoloji desteği ile geliştirilmesi [Developing technology supported instructional activities in a class of middle school students with intellectual disability]. Eğitim ve Bilim, 41(188), 197226. http://dx.doi.org/10.15390/EB.2016.6691

Sözbilir, M., Zorluoğlu, S. L., \& Kızılaslan, A. (2019). Görme yetersizliği olan öğrencilere yönelik geliştirilen fen etkinliklerinin bilimsel süreç becerileri öğrenimine etkisi: Madde ve 1s1 [The effect of activities prepared for students with visual impairment on the scientific process skills: Matter and heat]. Cumhuriyet Uluslararası Ĕgitim Dergisi, 8(1), 172-192. https://doi.org/10.30703/cije.463801 

INCELENMESI

Susam, E. (2012). Illköğretim 4. ve 5. sinıf fen ve teknoloji dersi ile matematik dersinde üstün zekâll ögrrencilere yönelik uygulamaların değerlendirilmesi [Evaluation of the practices for gifted students in maths and science and technology classes of the 4th and the 5th grades] (Tez Numarasi: 326656) [Doktora tezi, İnönü Üniversitesi]. Yükseköğretim Kurulu Ulusal Tez Merkezi.

Şağban, K. (2000). Fen bilgisi öğretimi amacıyla Ahmet Yesevi İsitme Engelliler İlköğretim Okulu 5. sinıf öğrencileriyle yapılan farkl öğretim uygulamalarının karşılaştırılması [A Comparison of different approaches to teaching science applied to class 5 students at Ahmet Yesevi primary school for hearingimpaired children] (Tez Numarasi: 97235) [Yüksek lisans tezi, Anadolu Üniversitesi]. Yükseköğretim Kurulu Ulusal Tez Merkezi.

Teke, D. (2017). Görme yetersizliğinden etkilenen bir kaynaştırma ögrencisine canlılarda enerji konusunun ögretimi [Teaching energy in living systems to a visually impaired students in an inclusive classroom] (Tez Numarası: 469418) [Yüksek lisans tezi, Atatürk Üniversitesi]. Yükseköğretim Kurulu Ulusal Tez Merkezi.

Tekin-İftar, E. (2012). Tek denekli araştırmalar ve temel kavramlar. E. Tekin-İftar (Ed.), Eğitim ve davranış bilimlerinde tek denekli araştırmalar [Single-subject studies in education and behavioral sciences] içinde (ss. 15-39). Türk Psikologlar Derneği Yayınları.

Tezcan, C. (2012). Zihinsel engelli çocuklara web destekli uzaktan eğitim sistemi kurulmast: Matematik ve fen bilgisi dersleri uygulamasl [Establishment of mentally retarded children's web-based distance education system: Application of mathematics and science courses] (Tez Numarası: 318319) [Yüksek lisans tezi, Trakya Üniversitesi]. Yükseköğretim Kurulu Ulusal Tez Merkezi.

Topbaş, S. (1998). Öğrenme güçlüğü gözlenenler. S. Eripek (Ed.), Özel eğitim [Special education] içinde (ss. 5572). Açıköğretim Fakültesi Yayınları.

Tosun, İ. E. (2019). Özel eğitime gereksinim duyan bireylere yönelik bilgisayar destekli destekli STEM eğitiminin etkileri [Influences of computer-basical STEM education on special education students] (Tez Numaras1: 602357) [Yüksek lisans tezi, Bursa Uludağ Üniversitesi]. Yükseköğretim Kurulu Ulusal Tez Merkezi.

Tuncer, A. T., \& Kahveci, G. (2009). Az gören 8. sınıf öğrencilerine kavram haritasıyla özet çıkarma becerisinin akran aracıllı̆̆ ile öğretimi [Teaching how to use of concept maps in summarizing texts by using peer mediatıon to 8th grade students with low vision]. Türk Eğitim Bilimleri Dergisi, 7(4), 853-877. https://dergipark.org.tr/tr/pub/tebd/issue/26109/275083

Türker, Ç., \& Çifci-Tekinarslan, İ. (2020). Zihin yetersizliği olan öğrenciye fen bilimleri dersinde uygulanan tanılayıcı dallanmış ağaç tekniğinin etkililik ve verimliliklerinin incelenmesi [An investigation of the effectiveness and efficiency of the diagnostic branched tree technique which is implemented in science lessons on the student with an intellectual disability]. Bolu Abant İzzet Baysal Üniversitesi Eğitim Fakültesi Dergisi, 20(1), 623-643. https://dx.doi.org/10.17240/aibuefd.2020.20.52925-638923

Umar, Ç. N. (2014). Karma öğrenme yöntemi ile farklllaştırllmış ögretim ortamının üstün zekâlı ve yetenekli ögrencilerin akademik başarllarına, eleştirel düşünme becerilerine ve yaratıclliklarına etkisi [The effects of differentiated curriculum with blended learning method on gifted students' academic achievement, critical thinking abilities and creative] (Tez Numarasi: 381932) [Doktora tezi, İstanbul Üniversitesi]. Yükseköğretim Kurulu Ulusal Tez Merkezi.

Villanueva, M. G., Taylor, J., Therrien, W., \& Hand, B. (2012). Science education for students with special needs. Studies in Science Education, 48(2), 187-215. https://dx.doi.org/10.1080/14703297.2012.737117

Wright, J. C., Knight, V. F., \& Barton, E. E. (2020). A review of video modeling to teach STEM to students with autism and intellectual disability. Research in Autism Spectrum Disorders, 70, 1-12. https://doi.org/10.1016/j.rasd.2019.101476

Yazıc1, F. (2017). 6. sinıf görme engelli ögrrencilere "vücudumuzdaki sistemler" ünitesinde yer alan kavramların ögretimi. [Teaching the concepts in 'systems in our body' unit to visually impaired students in 6th grade] (Tez Numarasi: 463093) [Doktora tezi, Atatürk Üniversitesi]. Yükseköğretim Kurulu Ulusal Tez Merkezi. 

INCELENMESI

Yeşildağ-Hasançebi, F., \& Günel, M. (2013). Argümantasyon tabanlı bilim öğrenme yaklaşımının dezavantajlı öğrencilerin fen bilgisi başarılarına etkisi [Effects of argumentation based inquiry approach on disadvantaged students' science achivement]. Illköğretim Online, 12(4), 1056-1073. https://dergipark.org.tr/en/pub/ilkonline/issue/8583/106608

Yıkmış, A., \& Varol-Özçakır, M. (2019). Zihin yetersizliği olan çocuklara hayvanların temel özelliklerinin kazandırılmasında doğrudan öğretim yöntemiyle sunulan kavram haritasının etkililiği [The effectiveness of the concept maps proposition provided by direct teaching methods for the promotion of the main characteristics of children with mild students]. Bingöl Üniversitesi Sosyal Bilimler Enstitüsü Dergisi, 9(17), 71-90. https://dx.doi.org/10.29029/busbed.523309

Yıldırım, A., \& Şimşek, H. (2018). Sosyal bilimlerde nitel araştırma yöntemleri [Qualitative research methods in the social sciences]. Seçkin Yayıncılık.

Yılmaz, H. C. (2017). Çoklu yetersizliği olan az gören çocuklara doğrudan öğretimle sunulan şematik düzenleyicinin bir fen konusunun ögretiminde etkisi [The effectiveness of schematic organizer presented through direct instruction on the teaching of a science content to the children with multiple disabilities and visual impairment] (Tez Numarasi: 486033) [Yüksek lisans tezi, Gazi Üniversitesi]. Yükseköğretim Kurulu Ulusal Tez Merkezi.

Yılmaz, H. U. (2018). Öğrenme güçlüğü tanılı kaynaştırma ögrencilerine yönelik hazırlanan fen deneyleri kilavuzunun değerlendirilmesi: "Madde ve değiş̧im" örneği [Evaluating a science experiments guidebook prepared for mainstreamed students with learning disabilities: 'Matter and change' sample] (Tez Numarası: 534768) [Yüksek lisans tezi, Trabzon Üniversitesi]. Yükseköğretim Kurulu Ulusal Tez Merkezi.

Yozgat, A. A., Özbek, N., \& Afacan, Ö. (2018). Hafif düzeyde zihinsel yetersizliği olan öğrencilere elementlerin isimlerinin doğrudan öğretim yöntemi kullanılarak öğretimi [Teaching of names of elements to students who have low level of mental incompetence by using direct teaching method]. Researcher: Social Science Studies, 6(1), 23-39. https://journals.indexcopernicus.com/api/file/viewByFileId/280886.pdf

Zorluoğlu, S. L., \& Sözbilir, M. (2017). Birbiri içinde çözünmeyen sıvılarda yoğunluk kavramının görme yetersizliğinden etkilenen öğrencilere öğretimi [Teaching the concept of density through insoluble liquids to visually impaired students]. Eğitimde Kuram ve Uygulama, 13(2), 211-231. https://doi.org/10.17244/eku.310219 


\section{Ankara University Faculty of Educational Sciences Journal of Special Education}

2022, 23(3), 721-750
REVIEW

Recieved Date: 23.12 .20

Accepted Date: 23.11 .21

OnlineFirst: 18.01 .22

\title{
A Systematic Review of Studies Conducted in Turkey on Science Teaching to Students with Intellectual Disabilities
}

\author{
Çiğdem Türker-Yıldırım (iD) 1
}

\begin{abstract}
Introduction: In order for the learning-teaching process of students with intellectual disabilities to be carried out effectively, different interventions should be used in line with their individual differences, developmental characteristics and educational needs. This study aimed to examine the studies conducted in Turkey on science teaching to students with intellectual disabilities.

Method: In this research conducted using document analysis, Google Scholar, Higher Education Council National Thesis Centre, and the Scientific and Technological Research Council of Turkey National Academic Network and Information Centre databases were reviewed and 17 studies that met the criteria were examined.

Findings: The majority of the studies employed direct instruction method and was provided through technologysupported teaching interventions. In addition, in most of the studies, it was found that as students acquired science concepts, knowledge and skills, their competence and success for the science course increased as well, and the studies carried out had a positive influence on their interests in and attitudes towards the science class.

Discussion: The findings obtained from the studies included in the research show that science concepts, knowledge and skills are acquired by students with intellectual disabilities. In this direction, it is seen that students with intellectual disability, whose learning speeds are slower than their typically developing peers, perform an effective learning-teaching process with the interventions carried out in line with their individual differences, developmental characteristics and educational needs.
\end{abstract}

Keywords: Special needs student, intellectual disabilities student, intellectual disabilities, science, science teaching, document analysis.

To cite: Türker-Yıldırım, Ç. (2022). A systematic review of studies conducted in Turkey on science teaching to students with intellectual disabilities. Ankara University Faculty of Educational Sciences Journal of Special Education, 23(3), 721-750. https://doi.org/10.21565/ozelegitimdergisi.843449

${ }^{1}$ Res. Assist., Bolu Abant İzzet Baysal University, E-mail: cigdem.turkeryildirim@ibu.edu.tr, https://orcid.org/0000-00021953-0138 


\section{Introduction}

Students with intellectual disabilities, holding an important place among students with special needs (Villanueva et al., 2012), are significantly different from their typically developing peers in terms of individual differences, developmental characteristics, and training needs (Ministry of National Education [MoNE], 2008; Özkan et al., 2013). This difference observed in students with intellectual disabilities results from the pace at which these students can learn, as they are slower than their peers with typical development patterns (MoNE, 2008; Villanueva et al., 2012). The aim of the education provided to students with intellectual disabilities who are slower learners than their peers but still able to learn concepts, knowledge and skills like their peers and continue to learn (Mete \& Yildırım, 2020), is, therefore, to maximize the possibility of students living independently and to meet their educational needs. In this way, it can be ensured that students with intellectual disabilities are taught the concepts, knowledge, and skills they will encounter in academic and social life (Alptekin, 2010; Eripek, 2011).

The internationally recognized United Nations Convention on the Rights of Persons with Disabilities, which aims to secure the provision of education to students with special needs and the students' rights to education, supports the provision of equal opportunity in education that has an important place in the education of students with special needs (International Convention, 2009). Supporting equality of opportunity in the education of students with special needs, the Science Curriculum aims to raise all students as science literate individuals regardless of their individual differences, developmental characteristics, and educational needs. According to this curriculum, students with special needs should be educated as science literate individuals, as is the case with students with typical development (MoNE, 2018). Carrying out the teaching process effectively by organizing and adapting the course content as well as the environment where teaching takes place plays an important part in teaching science concepts to students with special needs, and in raising them as science literate individuals (Scruggs et al., 1998). These effective teaching practices could ensure that students acquire the scientific concepts, knowledge, and skills they will encounter in daily life (Salend, 1998).

The present study aimed to provide a literature review on studies carried out in Turkey, which involved interventions used to teach science concepts, knowledge, and skills to students with intellectual disabilities, with the idea that revealing the general tendencies of studies on interventions for students with intellectual disabilities regarding the acquisition of science concepts, knowledge and skills could be beneficial for both theorists and practitioners in the field. The lack of such a work in the relevant literature was the main motivation behind the present study that could serve as a guide to other researchers aiming to conduct studies on science teaching to students with intellectual disabilities. In addition, it is hoped that the various interventions of different studies that are compiled in this study could be used as a reference list in the education of students with intellectual disabilities. Based on the aforementioned factors, this study aimed to examine the studies carried out in Turkey on interventions used to teach science concepts, knowledge, and skills to students with intellectual disabilities. For this purpose, the studies were examined according to several variables, namely the purpose, methods, the participants and their characteristics (grade level, number, gender, diagnosis), the science subject taught, interventions, intervention time, data collection tools, validity and reliability levels, and findings.

\section{Method}

For the purposes of this research, studies conducted in Turkey on interventions used to teach science concepts, knowledge, and skills to students with intellectual disabilities were qualitatively analysed. Data was collected through scanning Google Scholar (Google Scholar), Council of Higher Education (CoHE) National Thesis Centre and Turkey Scientific and Technological Research Council of the National Academic Network and Information Centre (TUBITAK ULAKBIM) databases using the keywords of "special education", "individual with special needs", "intellectual disabilities", and "science", after which the bibliography of each detected study was scanned manually. In the scanning process, firstly, databases were scanned with the aforementioned keywords and a pool was formed of a total of 56 studies found. In the second stage, studies that were not carried out with students with intellectual disabilities and that did not involve teaching science concepts, knowledge and skills through an intervention were removed from the pool. In the third stage, the bibliographies of the remaining studies were manually scanned, and the new studies found in the bibliography scanning were added to the pool. As a result, a total of 17 studies were found and these studies were examined according to the aforementioned criteria. For research purposes, the studies were chosen according to certain criteria, namely (a) the studies are related to the teaching of science concepts, knowledge, and skills, (b) The students in the study group have intellectual disabilities, (c) the intervention is aimed at students, (d) the studies were published between the years 2008-2020. To ensure coding reliability, the keywords selected were scanned by an independent expert in the same databases, 
the bibliographies of the obtained studies were manually scanned, and the suitability of the studies included in the study was checked. At the end of the reliability data collection process, the coder reliability was calculated as $100 \%$. Following this, the studies included in this research were categorized and analysed according to the purpose of the study, the methods of the study, the participants and their characteristics (grade level, number, gender, diagnosis), science subject taught, intervention, data collection tools, and findings.

When the aims of the studies were examined, it was seen that ten of these studies were conducted to examine the effectiveness of the intervention, three to compare the effectiveness of the intervention, and four to examine the change in competence, success, interest, and attitude. Methodological analysis revealed that singlesubject research methods were used in eight studies, while qualitative and quantitative research methods were used in six and three studies, respectively. It was observed that there were 131 (58 male and 31 female) participants in the 17 studies included in this research, with two studies not specifying the gender of the participants. The school grades of the participants were also examined, which revealed that one of the studies was conducted on kindergarten children, five on primary school pupils, twelve on middle school aged children, and one on high schoolers. In addition, in two of the studies, students studying in a special education and rehabilitation centre took part as subjects, in addition to another study that was conducted on students in a special education practice school.

When the science subject taught in the studies included in the study were examined, it was seen that the subjects of living things and life were taught in ten of the studies, matter and nature in five, physical events in three, and the earth and the universe in one. Analyses carried out on the interventions in the studies showed that six studies employed direct teaching method, four studies used technology-supported teaching, two studies utilised alternative assessment techniques presented by direct teaching method, with each of the remaining studies employing one of the methods of projectbased teaching, staggered teaching method, visual and auditory cues, 5E method, a fixed waiting-time teaching method, or STEM (Science Technology Enginering Mathematics) education interventions.

The durations of the interventions could be listed from the longest to the shortest as follows: 18 weeks, 14 weeks, 12 weeks, 11 weeks, five weeks, four weeks, two weeks, one week, three days, and two days. The total number of sessions and the duration of each session in studies where they were clearly stated can be summarized as ninety-six 40-minute sessions, sixty-five 90 -minute sessions, fifty 20 -minute sessions, forty-eight 40 -minute sessions, eighteen 40-minute sessions, twelve 28-minute sessions, twelve 25-minute sessions, ten 28-minute sessions, and two 80-minute sessions. Intervention time was not specified in four studies. There were four studies where number of sessions were specified $(91,36,15$, and 11 sessions) but no information was provided as to the duration of each session.

The findings on the data collection tools employed in the studies showed that the behaviour checklist and criterion-dependent measurement tools were used in eight and nine studies, respectively, while the remaining studies employed one of the tools of achievement test, observation form, interview form, worksheet, attitude scale, researcher diary, meeting record, report, diagnostic branched tree, and concept map data collection. When the validity and reliability measurement tools in the studies were examined, it was found that procedural reliability was used in seven of the studies, inter-observer reliability in six, social validity in three, Cronbach's alpha in two, data variation in two, coding reliability in two, and expert examination in two studies. The remaining studies employed one of the item difficulties, item discrimination, construct validity, content validity, consistency analysis, and confirmation analysis. There were five studies where validity and reliability were not measured.

When the findings of the studies were examined, it was observed that the intervention proved very effective in nine studies that focused on the effectiveness of the intervention, and in another study using the same measurement, intervention was found to be effective in two of the three participants. In three studies comparing the effectiveness of the intervention, it was found that both of the interventions compared were effective, with one study reporting one of the interventions to be more effective than the other. The results of the studies examining the change in competence, achievement, interest, and attitude revealed that the interventions increased the competence and success of the students towards the science course and led to a positive change in their interests and attitudes.

\section{Discussion}

In this study, a total of 17 studies carried out in Turkey between the years 2008 and 2020 that included interventions used to teach science concepts, knowledge, and skills to students with intellectual disabilities were 
examined. The studies were categorized and analysed according to the purpose of the study, the method of the study, the participants and their characteristics (grade level, number, gender, diagnosis), science subject taught, intervention, intervention time, data collection tool, validity and reliability data and findings. When the distribution of the studies in the study by years was examined, it was seen that the first study conducted in Turkey in which interventions were used to teach science subjects, concepts, knowledge, and skills to students with intellectual disabilities was in 2008. There was one study in 2009, one in 2012, four in 2016, two in 2018, four in 2019, and four studies in 2020. The increasing number of studies in this field could mean that researchers have turned to the field of teaching science subjects, concepts, knowledge, and skills to students with intellectual disabilities.

When the aims of the studies were examined, it was seen that studies examining the effectiveness of interventions used to teach science subjects, concepts, knowledge and skills to students with intellectual disabilities were at the forefront with ten studies, followed by four studies examining the change on proficiency, achievement, interest and attitude in the science course, and three comparing the effectiveness of interventions used for teaching science subjects, concepts, knowledge and skills. One reason why studies examining the effectiveness of interventions are larger in number may be that research findings serve to identify interventions that are effective in teaching science topics to students with intellectual disabilities, broadened by further research that help to distinguish which interventions are more effective. The use of interventions that have been scientifically proven to be effective may also help raise student interest and attitude towards the science course.

When the studies were examined in terms of the methodology they employed, it was found that the most frequently used method was the single-subject research method with eight studies, followed by qualitative research method with six studies. This could be attributed to the diversity of individual and developmental characteristics and educational needs of students with intellectual disabilities, which leads single-subject research methods, which help special needs students to be evaluated on their own (Tekin-Ifftar, 2012), and qualitative research methods to be widely used in these kinds of studies. When the aims of the studies were examined, it was seen that ten of these studies were conducted to examine the effectiveness of the intervention, three to compare the effectiveness of the intervention, and four to examine the change in competence, success, interest, and attitude. Methodological analysis revealed that singlesubject research methods were used in eight studies, while qualitative and quantitative research methods were used in six and three studies, respectively. It was observed that there were 131 (58 male and 31 female) participants in the 17 studies included in this research, with two studies not specifying the gender of the participants. The school grades of the participants were also examined, which revealed that one of the studies was conducted on kindergarten children, five on primary school pupils, twelve on middle school aged children, and one on high schoolers. In addition, in two of the studies, students studying in a special education and rehabilitation centre took part as subjects, in addition to another study that was conducted on students in a special education practice school.

When the science subject taught in the studies included in the study were examined, it was seen that the subjects of living things and life were taught in ten of the studies, matter and nature in five, physical events in three, and the earth and the universe in one. Analyses carried out on the interventions in the studies showed that six studies employed direct teaching method, four studies used technology-supported teaching, two studies utilised alternative assessment techniques presented by direct teaching method, with each of the remaining studies employing one of the methods of projectbased teaching, staggered teaching method, visual and auditory cues, 5E method, a fixed waiting-time teaching method, or STEM education interventions. The review of the interventions in the studies in question showed that the most frequently employed methods were direct teaching method and technology supported teaching methods, with 6 and 4 studies using these methods, respectively. The use of direct teaching method could be considered important, as it provides the opportunity to transfer the responsibility step by step from the teacher to the student in the teaching process, uses more than one teaching material in teaching by including plenty of examples, and helps to increase the success of students with special needs in the science course (Türker \& Çifci-Tekinarslan, 2020). The widespread use of the technology-supported teaching method reflects the common trends in teaching and is important for increasing the motivation and interest of students with special needs in the science course and for improving thinking and learning skills in students with visual and audio opportunities provided by technological aids (Sola-Özgüç \& Cavkaytar, 2016). Due to the fact that the studies varied greatly in their duration of intervention, no definitive assessment could be made. However, the data on intervention duration could be said to vary as a result of the difference in course contents and different interventions that were employed.

When it comes to the data collection tools employed in the studies, criterion dependent measurement tools were the most frequently used data collection tools with nine studies, followed by eight studies that employed 
behavioural checklists. Behavioural checklists and criterion-dependent measurement tools, which are informal measurement tools prepared by the teacher, help to determine the level of functioning of the students, aid the preparation of the teaching plan for the student, and the assessment of the level of learning according to the intended purpose (Kargin, 2007). It is thought that the finding in the present study regarding the predominance criterion-dependent measurement tools (Topbaş, 1998), which enable to clearly determine the student's performance needs, the student's progress level, and whether and the achievement of the determined goals were met according to the individual curriculum, is very important.

When the findings of the studies were reviewed, it was found that in the vast majority of the studies, students gained science concepts, knowledge and skills, students' competence and success for the science course increased, and the interventions led to positive changes in students' interests and attitudes. These findings are thought to be very important as they indicate that, in spite of their slower learning speed, the learning experiences of students with special needs are similar to those of their peers with typical development, and that students with special needs can acquire the concepts, knowledge and skills of the science course. In addition, in the study where learning aims were not met in one of the three study participants, it was suggested that the student could be provided with more time and a greater variety of materials to learn (Mete \& Yıldırım, 2020).

The present study can be considered important because it provides a review of the studies conducted in Turkey on interventions used to teach science concepts, knowledge, and skills to students with intellectual disabilities, and reveals which interventions have proved to be effective in the teaching process. It is thought that the results obtained will be useful for researchers working on the teaching of science concepts, knowledge, and skills for the science course to students with intellectual disabilities. In addition, it is thought that this study could be valuable for teachers working with students with intellectual disabilities with the information it provides about effective practices in science teaching. Future research may examine studies on how students with different disabilities gain science concepts, knowledge, and skills, as well as on the efficiency of other interventions aside from the ones reviewed here that are employed to teach science concepts, knowledge, and skills to students with special needs. 